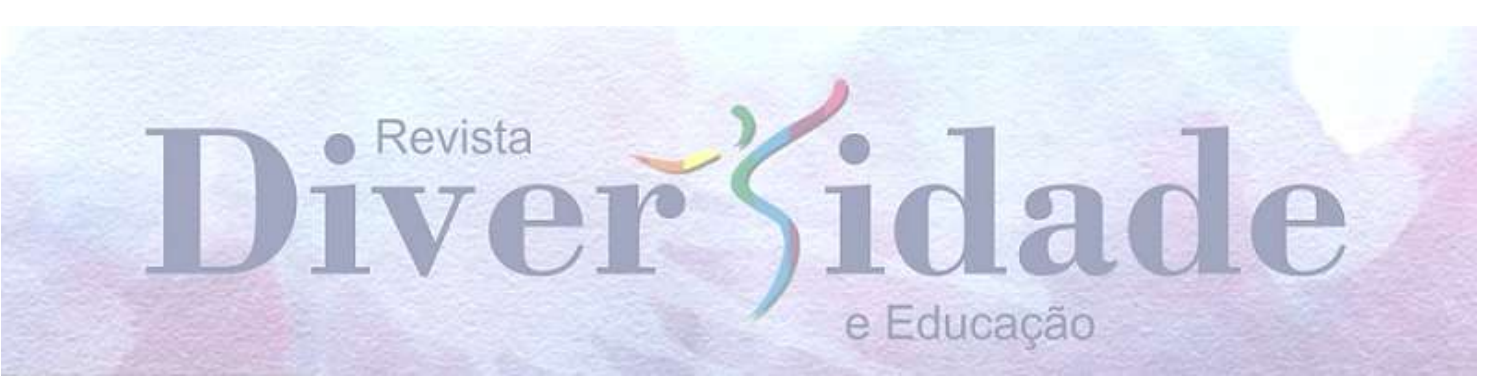

\title{
120 BATIMENTOS POR MINUTO: EDUCAÇÕES, CURRÍCULOS E O QUE PODE UM FILME NOS AFETAR EM RELAÇÃO AO HIVIAIDS?
}

\author{
120 LATIDOS POR MINUTO: EDUCACIONES, CURRÍCULOS Y ¿QUÉ \\ PUEDE AFECTARNOS UNA PELÍCULA EN RELACIÓN CON EL \\ VIH/SIDA?
}

\section{BEATS PER MINUTE: EDUCATIONS, CURRICULUMS AND WHAT CAN A MOVIE AFFECT US IN RELATION TO HIVIAIDS?}

\author{
Tiago Amaral Sales ${ }^{1}$
}

\section{RESUMO}

Batimentos que se aceleram em meio a festas, protestos, transas, hospitais, laboratórios, velórios, casas e ruas, entre celebrações, desejos, lutos e lutas. Este artigo busca cartografar o filme francês "120 Batimentos por Minuto" (2017), percorrendo educações e currículos engendrados em torno dele. A partir das narrativas audiovisuais, penso nos afetos possíveis em relação à epidemia de HIV/aids em diálogos entre a década de 1990, na qual o filme se passa, e a contemporaneidade. O filme é visto como território que engendra pedagogias e currículos menores e desviantes, abrindo brechas ao criar conexões entre HIV/aids, potência de vida e desejo, fugindo de educações maiores que estigmatizam as vivências com HIV/aids e participam da manutenção de políticas de silêncio, exclusão, como também de morte civil e biológica.

PALAVRAS-CHAVE: Cartografia. Cinema e Educação. HIV/aids.

\section{RESUMEN}

Latidos que se aceleran en medio de fiestas, protestas, sexos, hospitales, laboratorios, funerales, casas y calles, entre celebraciones, deseos, lutos y luchas. Este artículo busca mapear la película francesa "120 Latidos por Minuto" (120 Beats per Minute, 2017),

\footnotetext{
${ }^{1}$ Licenciado e Bacharel em Ciências Biológicas pelo Instituto de Biologia da Universidade Federal de Uberlândia (INBIO/UFU). Mestre e Doutorando em Educação no Programa de Pós-Graduação em Educação da Universidade Federal de Uberlândia (PPGED/UFU). Graduando em Pedagogia pela Universidade Estácio de Sá (UNESA) e pós-graduando em Pedagogia Universitária pela Universidade Federal do Triângulo Mineiro (UFTM). Integrante do UIVO - Matilha de estudos em criação, arte e vida (UFU); e do GPECS - Gênero, corpo, sexualidade e educação (UFU). Bolsista CAPES. E-mail: tiagoamaralsales@gmail.com
} 
atravesando las educaciones y los currículos engendrados alrededor de ella. Desde las narrativas audiovisuales, pienso en los posibles afectos en relación a la epidemia del VIH/SIDA en los diálogos entre la década de 1990, en la que transcurre la película, y la época contemporánea. La película se ve como un territorio que engendra pedagogías y currículos más pequeños y desviados, abriendo lagunas al crear conexiones entre el VIH/SIDA, el poder de la vida y el deseo, huyendo de educaciones más grandes que estigmatizan las experiencias con el VIH/SIDA y participando en el mantenimiento de políticas de salud, silencio, exclusión, así como de muerte civil y biológica.

PALABRAS-CLAVE: Cartografía. Cine y Educación. VIH/SIDA.

\section{ABSTRACT}

Beats that speed up in the midst of parties, protests, sex, hospitals, laboratories, funerals, houses and streets, between celebrations, wishes, mourning and fights. This paper seeks to map the french movie "120 Beats per Minute" (2017), going through educations and curricula engendered around it. From the audiovisual narratives, I think of the possible affects in relation to the HIV/AIDS epidemic in dialogues between the 1990s, in which the movie takes place, and contemporary times. The movie is seen as a territory that engenders smaller and deviants pedagogies and curricula, opening gaps by creating connections between HIV/AIDS, the power of life and desire, running away the larger educations that stigmatize experiences with HIV/AIDS and participate in the maintenance of health policies, silence, exclusion, as well as civil and biological death.

KEYWORDS: Cartography. Cinema and Education. HIV/AIDS.

$$
* * *
$$

\section{Introdução}

Um encontro entre corpos. Cinema? Televisão, sala de casa, quarto, computador, celular, sala de cinema, palco de festival. Um ambiente em que seja possível que o foco se direcione às imagens e sons. Uma sala escura com boa acústica, um corpo com seu notebook, um celular no ônibus com um fone de ouvido. Um corpo-humano e um corpo-filme podem ganhar intensidades a partir das suas multiplicidades de encontros. Imagens, sons, narrativas, sensações. O que pode um filme nos afetar? Como estes afetos atuam em nossos corpos, subjetividades e vidas? Pensar no encontro entre corpoe-filme é ver a vida que habita em uma produção audiovisual, nos processos que levaram a sua criação e produção, como também nas educações por ela engendradas.

O cinema e as diversas produções audiovisuais atuam nos processos de construção de nossas subjetividades, visões de mundo e desejos, instaurando pedagogias. Guacira Lopes Louro trata “o cinema como uma pedagogia cultural” (2000, p. 424). Para a autora, 
Muitos espaços e processos sociais, além da escola, constituem-se em instâncias educativas. As formas pelas quais essas instâncias interpelam os sujeitos diferem, contudo, daquelas em ação nas escolas e, conseqüentemente, também seus efeitos podem ser distintos (LOURO, 2000, p. 422).

O cinema também assume-se como instância educativa e possibilidade de engendrar aprenderes, porém seu encontro com os corpos humanos não é neutro e nem recebido em passividade, como afirma Louro:

Mulheres e homens não são, diante dessa e de outras instâncias formativas, passivos receptores de mensagens, normas ou códigos. Eles e elas participam ativamente dos processos pedagógicos em ação. Distintas relações do sujeito com a imagem fílmica podem ocorrer: acolhida, ruptura, conformidade, resistência, crítica ou imprevisíveis combinações dessas e de outras respostas (LOURO, 2000, p. 424).

Diferentes conexões podem acontecer no encontro entre corpo, imagem e som. Um conceito importante para pensar nas produções audiovisuais é o endereçamento. As formas como produções audiovisuais endereçam o que se produz ao público influenciam diretamente como serão percebidas pelas pessoas e os afetos a serem agenciados. Estes endereçamentos não são lineares, nem tampouco inocentes, como afirma Elizabeth Ellsworth:

\begin{abstract}
As relações entre a forma como os textos cinematográficos endereçam seu público e a forma como os espectadores reais lêem os filmes não são nítidas ou puras - elas tampouco são lineares ou causais. E a busca por relações nítidas e puras, lineares e causais não é uma busca inocente (ELLSWORTH, 2001, p. 40).
\end{abstract}

A partir das não-linearidades, confusões, diferenças e atritos, os encontros podem se potencializar.

Se fosse possível obter ajustes perfeitos entre as relações sociais e a realidade psíquica, entre o eu e a linguagem, nossas subjetividades e nossas sociedades seriam fechadas. Completas. Acabadas. Mortas. Nada a fazer. Nenhuma diferença. Não haveria nenhuma educação. Nenhuma aprendizagem (ELLSWORTH, 2001, p. 56).

A aprendizagem acontece nas diferenças e nos encontros por elas engendrados, sejam estes agenciados pelo cinema ou pelas aulas. "Que tal se, da mesma forma que ocorre entre um filme e seu espectador, a relação de um estudante com o currículo fosse um evento confuso e imprevisível que constantemente excedesse tanto a compreensão quanto a incompreensão?” (ELLSWORTH, 2001, p. 60). 
Envolto nessas conexões entre educação e linguagens audiovisuais, penso nos encontros-aula que acontecem através dos encontros-cinema. Encontros entre imagens, sons, histórias e geografias. Encontros permeados por afetos que atuam na construção de subjetividades, em produções de aprendizados pelo corpo que vê, escuta e sente. Aulas-cinema? Currículos-audiovisuais?

O currículo não se limita a contextos escolares, permeando outras instâncias da vida humana. Pensando a partir das teorias pós-críticas e suas contaminações com a educação, Tomaz Tadeu da Silva reflete que "o cultural torna-se pedagógico e a pedagogia torna-se cultural” (SILVA, 1999, p, 139). O autor afirma que (1999, p. 139):

Se é o conceito de "cultura" que permite equiparar a educação a outras instâncias culturais, é o conceito de "pedagogia" que permite que se realize a operação inversa. Tal como a educação, as outras instâncias culturais também são pedagógicas, também têm uma "pedagogia", também ensinam alguma coisa. Tanto a educação quanto a cultura em geral estão envolvidas em processos de transformação da identidade e da subjetividade. (...) Da perspectiva da teoria curricular, poderíamos dizer que as instituições e instâncias culturais mais amplas também têm um currículo (SILVA, 1999, p. 139).

Somos sujeitos culturais na medida em que também somos sociais. Nos nossos encontros, engendramos processos, criamos artefatos e também aprendemos a partir dessas conexões que fazemos em nossos trajetos. Estas produções culturais carregam e forjam currículos nos corpos que com elas se encontram. Sendo as produções audiovisuais também criações culturais localizadas em contextos específicos, quais currículos carregam? E quais afetos estes currículos fílmicos podem agenciar?

Tomaz Tadeu (SILVA, 2002), em outro texto, pensa no currículo a partir de leituras de Gilles Deleuze, Félix Guattari e Baruch Spinoza, refletindo que:

Em geral, um currículo é definido por um conjunto de saberes. (...) E se o currículo, em vez disso, fosse concebido como um encontro, uma composição? Isso não mudaria tudo? Poderíamos começar por imaginar que corpos, os mais heterogêneos, os mais disparatados, os mais improváveis ("sorvete flambado com suspiro"), se encontram e se combinam no currículo, para compor um agenciamento-currículo particular. (...) Corpos de todo tipo. Humanos. Animais. Animados. Inanimados. Institucionais. Lingüísticos. Uma mistura variada. Ao infinito. Encontro de corpos, considerados sempre sob duas relações: a de movimento, com maior ou menor velocidade, e a dos afectos (...) Fazer do currículo, pois, uma pura experiência spinoziana. Deleuziana. Cultivar os bons encontros. Aqueles que nos ajudam a nos apartar do efêmero e do contingente para experimentar um gostinho do infinito e do eterno. Criar afectos e perceptos que, como as obras de arte, sejam como experiências de eternidade. Porque tem a imanência de uma vida, 
um currículo assim jamais deixa o solo. Mas ele se torna leve (SILVA, 2002, p. 55-56).

Assim, me coloquei em movimentos de traçar cartografias ${ }^{2}$ por meio dos afetos possíveis a partir do encontro entre corpos - meu corpo, corpos-filme, corpos-e... -, pensando nos currículos (im)possíveis em um filme: currículos em brechas, encontros e fugas. Forjei uma cartografia audiovisual ${ }^{3}$ em intensidades, modulações, velocidades, misturando-se com o assistir-e-afetar-se audiovisual que permeia mais do que os olhos e ouvidos: atravessa todo um corpo que vibra na medida em que assiste e se conecta com o filme.

Sobre o pesquisar-cartográfico, Suely Rolnik (2011, p. 23) afirma que:

Sendo tarefa do cartógrafo dar língua para afetos que pedem passagem, dele se espera basicamente que esteja mergulhado nas intensidades de seu tempo e que, atento às linguagens que encontra, devore as que lhe parecerem elementos possíveis para a composição das cartografias que se fazem necessárias (ROLNIK, 2011, p. 23).

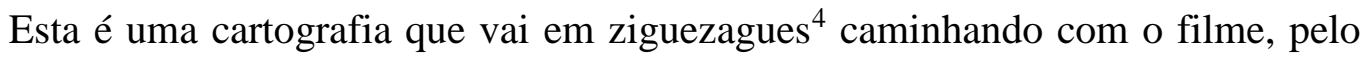
filme, vazando do filme, indo em outras direções. Como a produção audiovisual pode me afetar e quais afetos pedem passagem a partir desse nosso encontro? O que aprendo com suas cenas e narrativas? De que formas sou deslocado, desestabilizando noções pré-existentes? Quais marcas são forjadas nas minhas subjetividades nestes encontros?

O filme que me afetou e embrionou a produção dessa cartografia foi " 120 Batimentos Por Minuto" (120 Battements par Minute, 2017). Produzido na França pelo diretor marroquino Robin Campillo, as narrativas presentes no audiovisual se passam nos anos 1990, também na França, em meio à explosão da epidemia de HIV/aids, em momentos em que não existiam tratamentos eficazes, sendo a infecção pelo vírus potencialmente fatal. Nessa ausência de possibilidades terapêuticas disponibilizadas pelas ciências médicas, demandava-se imensa luta coletiva e ativismo para tentar preservar a vida dos corpos infectados pelo vírus. Em cenários de horror, doença e

${ }^{2}$ Outras cartografias por mim realizadas são "Cartografias do cerrado: devires, marcas e forrageios em processos de pesquisa-trans-formação de um biólogo" (SALES, 2020a) e "Cartografias de vida-e-morte em territórios pandêmicos: marcas-ferida, necro-bio-políticas e linhas de fuga" (SALES; ESTEVINHO, 2021a).

${ }^{3}$ Outras cartografias audiovisuais por mim realizadas são "Carta para além dos muros biológicos: pistas de uma biologia menor e afetos possíveis com um documentário sobre HIV/AIDS" (SALES; ESTEVINHO, 2021b) e "Os ventos do norte também podem mover moinhos? 'Como sobreviver a uma praga' e respostas à epidemia de HIV/aids" (SALES, 2021). Ambos os textos cartografaram produções cinematográficas sobre HIV/aids.

4 Aqui utilizo ziguezague em referência ao conceito de ziguezague proposto por Deleuze (DELEUZE; PARNET, 1995). 
morte, intensificados por negligências e silêncios estatais e científicos, os personagens do filme forjam territórios de intenso enfrentamento de instituições poderosas e opressoras, na luta constante pela vida, buscando afirmar seus desejos, mesclando imagens da fragilidade e finitude com força, prazer, desejo e tesão de uma existência.

Apresentado no Festival de Cannes no ano de 2017 e premiado com o Grand Prix, é possível ver sua sinopse e ficha técnica no site do festival. A sinopse ${ }^{5}$ traz que: “Começo dos anos 1990. Com a aids já tendo ceifado incontáveis vidas por aproximadamente dez anos, ativistas do ACT UP - Paris multiplicam ações para combater a indiferença geral. Nathan, um recém-chegado no grupo, tem seu mundo mexido por Sean, um militante radical, que joga suas últimas partículas de força na luta".

Meu encontro com a produção audiovisual ocorreu através das redes sociais ao acompanhar páginas que discutem temas relacionados à sexualidade, corpo, HIV/aids, infecções sexualmente transmissíveis (ISTs) e temáticas que se relacionem às pessoas LGBTQIA $+{ }^{6}$. Ao assisti-lo, fui afetado pela potência e sensibilidade que este percorre por temas tão sensíveis e caros que se referem aos movimentos de luta das pessoas vivendo com HIV/aids, como também as subjetividades destes grupos historicamente marginalizados e estigmatizados.

O filme se passa em plena ascensão da epidemia de HIV/aids, período no qual muitas pessoas eram acometidas pela doença e morriam sem ter sequer acesso a tratamentos eficazes. Hoje, cerca de três décadas depois, somam-se no mundo aproximadamente 32 milhões de mortes em decorrência da aids e 38 milhões de pessoas que vivem com o vírus, segundo a UNAIDS (2020). Os tratamentos para contenção viral se desenvolveram e conseguiram atingir grande eficácia, podendo frear a replicação do vírus nos corpos infectados, preservando a imunidade das pessoas vivendo com HIV que tenham acesso a possibilidades de realizar um tratamento corretamente e estejam utilizando a medicação de maneiras adequadas, porém, mesmo

${ }^{5}$ O trecho original da sinopse encontrava-se em inglês, sendo "Early 1990s. With AIDS having already claimed countless lives for nearly ten years, Act up-Paris activists multiply actions to fight general indifference. Nathan, a newcomer to the group, has his world shaken up by Sean, a radical militant, who throws his last bits of strength into the struggle". Já a ficha técnica afirma que o responsável pela direção é Robin Campillo, pela música é Arnaud Rebotini, pelo roteiro e diálogo são Philippe Mangeot e Robin Campillo, pela direção de fotografia é Jeanne Lapoirie, pela edição do filme é Robin Campillo, pelo som é Jean-Pierre Laforce, Valérie Deloof e Julien Sicart." Tradução minha. Disponível no site <https://www.festival-cannes.com/en/films/120-battements-par-minute> (acessado em 25/02/2021).

${ }^{6}$ Sigla para os termos Lésbicas, Gays, Bissexuais, Transexuais/travestis, Queer, Intersexos, Assexuados e o "+” para outras possibilidades de existência. Questiono aqui se poderia o mais (+) referenciar as pessoas com sorologia positiva para o vírus HIV, tão marcante na história e presente desses grupos citados? 
assim, no ano de 2019, aproximadamente 690 mil pessoas morreram em decorrência da aids no mundo (UNAIDS, 2020, p. 1).

Trilho essas cartografias durante outra pandemia ${ }^{7}$ que também deixa milhões de mortos mundo afora. Busco possibilidades de fuga de um deserto-subjetivo instaurado em territórios pandêmicos ${ }^{8}$, cerceando o desejo.

Cartografar um filme é caminhar pelas forças e potências que vibram em uma produção cinematográfica, ganhando velocidade por entre os afetos que me atravessam, fugindo de rigidezes e pretensões de construir certezas absolutas. Cartografar em fugas?

"Fugir é traçar uma linha, linhas, toda uma cartografia. Só se descobre mundos através de uma longa fuga quebrada", afirmam Gilles Deleuze e Claire Parnet (1998, p. 30). Nestas fugas-cartográficas pelos trajetos audiovisuais não busco trazer certezas nem instaurar verdades concretas sobre uma produção, mas pensar com ela, além dela, a partir dela, em conexões com o que vaza e contamina quem assiste. A partir de narrativas que ressoam acontecimentos ficcionais do passado, me afeto em movimentos para pensar no contemporâneo, no que nos atinge agora, buscando desestabilizar imagens e noções que insistem em permanecer, associadas a moralidades que estigmatizam as experiências afetadas pelo HIV e pela aids.

\section{Trajetos: Cartografias em batimentos, cenas e afetos}

Silêncio. Batimentos. Velocidades. Conversas no escuro. No silêncio, força para o grito, o protesto, o posicionamento, a manifestação. O caos toma conta das cenas iniciais, instaurando outros ritmos. Um corte. Na cena seguinte ocorre uma apresentação do coletivo ACT UP.

Sobre o coletivo de enfrentamento da aids ACT UP, o ensaísta e filósofo Eduardo Jardim afirma que:

O ACT UP, criado em 1987, foi o grupo de maior destaque nesse contexto. Um pequeno círculo se formou em Nova York, reunindo-se todas as segundas-feiras à noite, com o objetivo de providenciar suporte material e psicológico para a população doente. Em seguida, foram criados meios de forçar o governo e os laboratórios farmacêuticos a acelerar a produção e a comercialização de medicamentos. Àquela altura, a única droga disponível era o AZT, extremamente tóxica e nem sempre eficaz. Seria preciso esperar mais de dez anos pela liberação de

${ }^{7}$ Em referência à pandemia de covid-19.

${ }^{8}$ Inspirado em Paulo Buenoz (2009). 
novos remédios. Por este motivo, os dois lemas da organização foram: Silêncio $=$ Morte e Remédios em nossos corpos (JARDIM, 2019, p. 24).

O filme se passa na França, em meio às movimentações do ACT UP em Paris. Participar do movimento era automaticamente ser visto, lido, reconhecido, marcado, rotulado como soropositivo para o HIV. As cenas iniciais são acompanhadas por uma tensão a todo momento entre vida e morte, saúde e doença. Nas cores vibrantes que as compõem, surgem anúncios de mortes. A morte é tida pelos militantes como política, sendo uma marca do coletivo-ativista, para lembrar a todo momento que uma epidemia estava em curso e matando tantos diariamente.

Cenas que inquietam em pulsações, imagens e afetos. Vida-sangue. Coletivoprotesto. Protesto-sangue. Protesto-vida. Protesto-celebração-vida em meio à morte. Protesto-raiva em meio à vida. Protesto em defesa da vida, impulsionado pela raiva, raiva-política. Diálogos, atritos, impasses que movimentam um coletivo-manada.

Franny ouve uma emissão sobre lobos. Eu lhe digo: gostarias de ser um lobo? Resposta altiva - é idiota, não se pode ser um lobo, mas sempre oito ou dez lobos, seis ou sete lobos. Não seis ou sete lobos ao mesmo tempo, você, sozinho, mas um lobo entre outros, junto com cinco ou seis outros lobos. O que é importante no devir-lobo é a posição de massa e, primeiramente, a posição do próprio sujeito em relação à matilha, em relação à multiplicidade-lobo, a maneira de ele aí entrar ou não, a distância a que ele se mantém, a maneira que ele tem de ligar-se ou não à multiplicidade (DELEUZE; GUATTARI, 2011, p. 54-55).

Um devir-lobo, como propõem os filósofos franceses Gilles Deleuze e Félix Guattari (2011). Devir-lobo pela força coletiva, em manada. Não se é lobo sozinho, assim como não se luta neste ativismo em defesa da vida individualmente. O coletivo é a potência e força da manada, não aniquilando subjetividades, mas movimentando e ganhando impulso pelas diferenças e, também, pelos atritos e explosões. Entre correntezas de conservadorismo, ódio e invisibilidade da doença, o coletivo grita.

Cenas de reuniões que se misturam com protestos. Invasões de laboratórios, rompendo com a hierarquia invasiva dos laboratórios farmacêuticos através de explosões de vida. Cenas de invasão de um grande laboratório farmacêutico, presentes na Imagem 1. Invasão ou ocupação do poder-farmacêutico-científico? Tentativa de subverter as relações de poder, de pegar para si a tecnologia lá produzida antes que seja tarde demais. 
Bombas de tinta cor-de-sangue mancham, contaminam e marcam por onde os ativistas passam. O sangue que permite a vida e movimenta o corpo, também potencialmente ocupado por vírus e outros seres diminutos, conecta com imagens de aids, sexo, prazer e dor.

IMAGEM 1: Protestos: invasão-ocupação laboratorial.

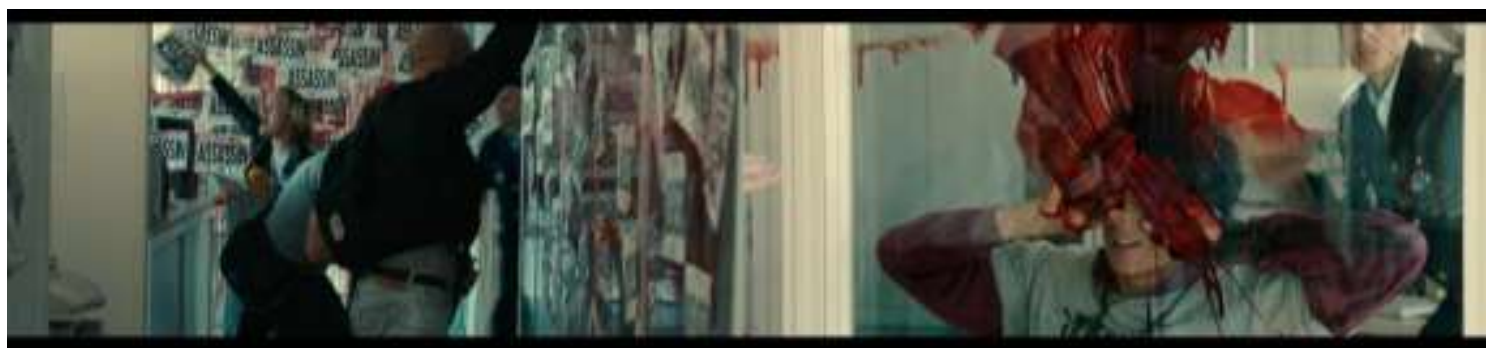

Fonte: Sequência de dois registros de cenas dos minutos 19 e 20 do filme "120 Batimentos por Minuto" (2017).

As cenas migram do confronto no protesto no laboratório ao atrito em espaços públicos, em aglomerações, risos e conversas dos ativistas enquanto andam de metrô, sendo atravessados por olhares cortantes de outros personagens no vagão que questionam e tentam oprimir suas existências. Existências que fogem às normas heteronormativas, gays, soropositivas, marginais. Confronto em vidas-protesto.

Cenas que continuam pela cidade de Paris vista pela janela do metrô. Rapidamente acontece uma pausa e mudança de foco, sem que as cenas parem, para que um personagem ingira seus comprimidos. "Há momentos que me dou conta de como a aids mudou minha vida. É como se eu vivesse mais intensamente as coisas, como se eu visse o mundo de outro modo. Como se ele tivesse agora mais cores, mais barulhos, mais vida. De manhã, principalmente" relata Sean ${ }^{9} \operatorname{logo}$ após tomar suas pílulas. Uma reflexão-desabafo que rapidamente cede espaço para risos que desencadeiam afetos em movimentos que migram da sensibilização à ironia. Na irônica fala de Sean, deixa-se no ar micropartículas de dúvidas de até onde a aids mudou sua vida ou não, porém acordar pelas manhãs continua sendo difícil, talvez mais até do que antes, relata o personagem.

A partir da fala de Sean, antes da virada irônica, recordo de uma reflexão desenvolvida por Gilles Deleuze ao ser entrevistado por Claire Parnet em seu abecedário (1995). O filósofo, ao ser questionado sobre suas experiências com a doença, em especial em relação à tuberculose que o acompanhou durante anos, relata que a doença e uma "saúde fraca" o auxiliaram no processo de estar à escuta da vida. Ele

${ }^{9}$ Fala realizada nos minutos 22 e 23 do filme. 
afirma que "estar à escuta da vida é muito mais do que pensar em sua própria saúde. Mas acho que uma saúde fraca favorece este tipo de escuta. (...) É verdade que não se pode pensar sem estar em uma área que exceda um pouco as suas forças, que o torne mais frágil” (DELEUZE; PARNET, 1995, p. 49). Esta fragilidade desencadeada por processos de adoecimento podem engendrar sensibilidades outras em relação ao mundo.

As cenas no metrô se misturam com flashes de dança, boate e música. Flertes, luzes, vidas pulsantes. Beijos intensos em movimentos de celebração, em ecstasy-vida. Micropartículas podem ser vistas pela luz povoando todo o território. Vírus? Na Imagem 2 é possível ver partículas-vírus compondo paisagens virais. Adentrando vidas, corpos e histórias, as micropartículas viralizam e compõem paisagens.

IMAGEM 2: Partículas-vírus ou paisagens-virais.

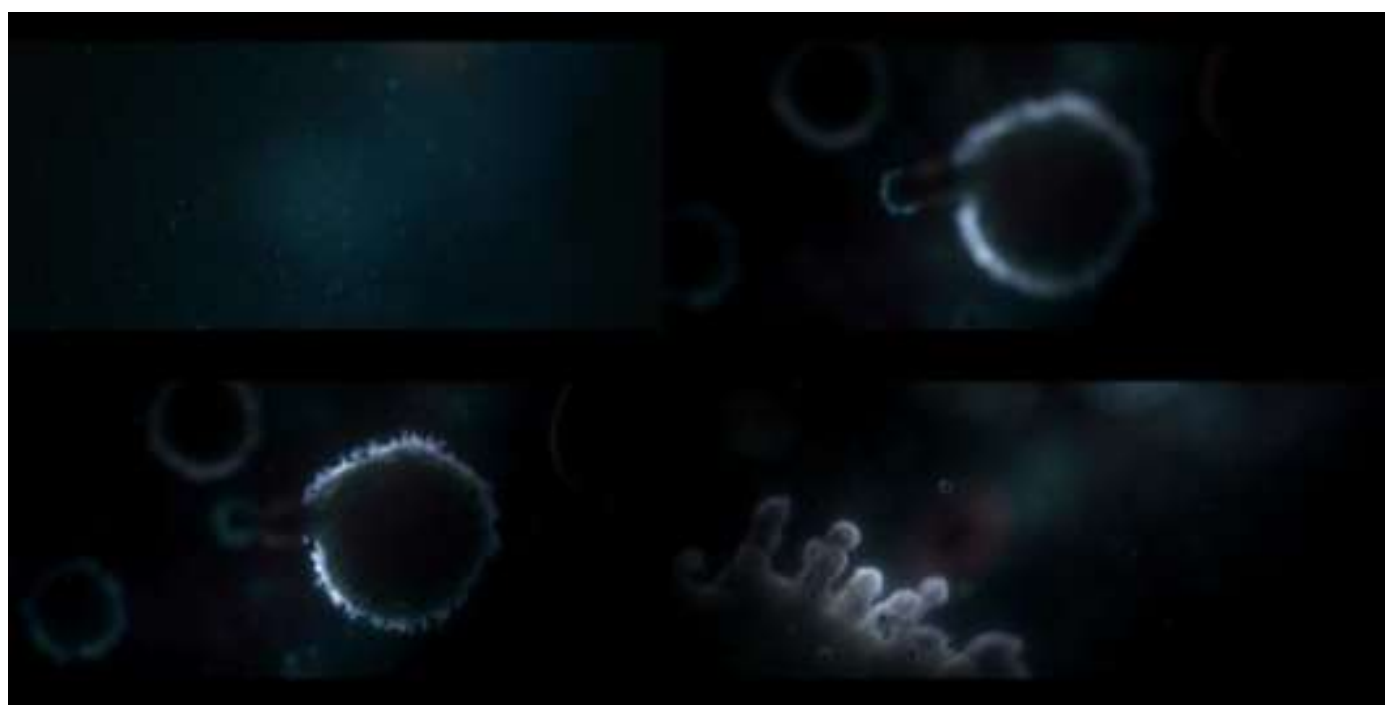

Fonte: Sequência de quatro registros de cenas dos minutos 25 e 26 do filme "120 Batimentos por Minuto"(2017).

No filme, o vírus e a aids também são personagens e compõem paisagens multiespécies, como propõe a antropóloga Anna Tsing (2019). A autora afirma que "A paisagem é um ponto de encontro para os atos humanos e não humanos e um arquivo de atividades humanas e não humanas do passado" (TSING, 2019, p. 17). Vírus, microscópicas possibilidades de "vida"10, compõem as paisagens audiovisuais, participando de histórias, afetando vidas humanas e não humanas, atuando em subjetividades. Vírus que adentram corpos, percorrem os órgãos e infectam as células de defesa. Micro-vidas capazes de causar intensas mudanças e também estragos. A aids,

${ }^{10}$ Coloco entre aspas o termo "vida" que se refere ao vírus em decorrência das discussões presentes nas ciências biológicas acerca da categorização ou não do vírus como ser vivo, questão esta que não é foco neste trabalho. Questiono: O que é uma vida? 
doença que levou e continua levando tantos à morte, também entra como personagem e compõem as paisagens corporais, subjetivas, geográficas e históricas. Vidas afetando outras vidas e carregando a possibilidade de encerrar uma existência.

As cenas que se seguem permeiam estudos em bando, novamente em devir-lobo. Os ativistas debruçam-se sobre temas como antirretrovirais, transcriptase reversa, moléculas, infecções, contaminando-se de conhecimentos biomédicos-científicos em desejos de instaurar resistências ao poder médico. Ódio ao poder-médico, como comenta Deleuze: “Tenho um profundo ódio, não pela pessoa dos médicos que, em geral, são encantadores, mas pelo poder médico e pela maneira como usam este poder" (DELEUZE; PARNET, 1995, p. 49). Mas, como reflete o filósofo francês Michel Foucault, "não é que a vida tenha sido exaustivamente integrada em técnicas que a dominem e gerem; ela lhes escapa continuamente" (FOUCAULT, 2013, p. 155-156). A vida cria fugas e resistências entre poderes capilares que tentam capturá-la, em tramas de poder-e-resistência.

Os movimentos sociais do ACT UP se fortaleciam também pelo estudo coletivo, como na Imagem 3, através da compreensão dos territórios científicos que, mais do que nunca, adentravam e precisavam adentrar os corpos-vivos naquele momento infectados pelo HIV. As novas moléculas bioquímicas antirretrovirais carregavam a potência da esperança ao possibilitarem outras formas de tratamento ao HIV e à aids que fossem mais fortes e eficazes que os poucos medicamentos naquele momento disponíveis.

IMAGEM 3: Saberes e práticas em resistências.

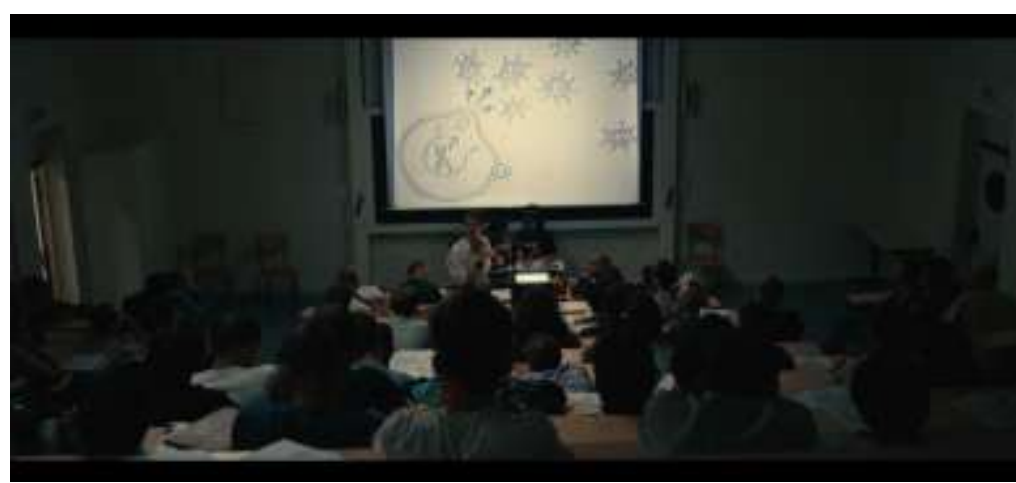

Fonte: Registro da cena presente no minuto 27 do filme "120 Batimentos por Minuto" (2017).

Cenas de diálogos que se entremeiam com chuva, plantas, água em gotículas, micropartículas que molham e povoam o solo, na medida em que o alimentam. 
Conversas discutem as possíveis esperanças de fuga ao $\mathrm{AZT}^{11}$, antirretroviral disponível naquele momento como tratamento para a infecção pelo HIV, porém apresentando pouca eficácia, alta toxicidade e muitos efeitos colaterais. A ânsia por novas opções de tratamento aumenta e a luta pela vida também.

Nathan questiona, nesta cena do diálogo, por estudos relacionados às vacinas para o HIV. Em tons de sarcasmo, é respondido que o coletivo foca sua atenção em outras questões além das vacinas, pois muitos não tiveram tempo de esperá-las. As demandas são urgentes, não negando a importância da vacina e de diversas possíveis formas de prevenção, mas, naquele momento, a atenção voltava-se para remédios que impedissem que mais vidas fossem rapidamente levadas pela aids.

Enquanto o diálogo continua sobre vacina e outros trâmites do grupo, um integrante silenciosamente vai desfalecendo e cai no chão. O personagem é Jérémie. Ele é levantado com auxílio de seus novos companheiros de militância. A pouco chegara ao coletivo trazendo muitas dúvidas. Fora infectado recentemente e, rapidamente, apresentou graves pioras. Entre o desejo por vacinas para evitar a infecção, a urgência explode de um corpo que, em pouco tempo de infecção pelo vírus, é enfraquecido e fragilizado.

As cenas seguintes se passam em novas reuniões enquanto Jérémie apalpa silenciosamente seus gânglios no pescoço e toma uma pílula, em meio ao cotidianomilitância e suas demandas. As reuniões consistem em encontros que acontecem entre corpos dissidentes e, mesmo nessa condição politicamente produzida de marginalização, preconceito e estigma, também vivenciam discriminações e negações realizadas dentro das próprias condições de dissidência: ativistas relatam que, ao tentarem divulgar medidas de prevenção à infecção, foram agredidos por homossexuais que não queriam ser associados à epidemia. Mas como grupos historicamente excluídos e vulnerabilizados assumem posturas de negação das condições às quais foram submetidos? Talvez, revisitar a história da epidemia possa ajudar a compreender essas cenas.

A chegada da aids coincidiu com o fortalecimento dos grupos
conservadores que, no caso dos Estados Unidos, se integraram na
campanha e, posteriormente, na gestão de Ronald Reagan na
presidência (1981-1989). A aids tinha tudo para se tornar um alvo
preferencial. (...) Sua transmissão se deu, em um primeiro momento,

11 AZT é abreviação para o medicamento antirretroviral zidovudina, um dos primeiros a serem disponibilizados para tratamento da infecção pelo HIV e adoecimento pela aids. 
por via sexual, e ela logo se espalhou no meio homossexual. Para os conservadores, isto só poderia ser resultado da depravação e da decadência dos costumes (JARDIM, 2019, p. 42-43).

O conservadorismo abocanhou a aids como um prato cheio para nutrir suas posturas violentas e estigmatizantes em relação aos corpos já marginalizados, como de homossexuais, pessoas trans e travestis, prostitutas, negros e usuários de drogas. "Incide sobre a AIDS, como uma luz que não elabora contornos, indefinidos fluxos de problematizações sociais que ela parece reunir; como um - lago ou um abismo - que recebe muitos afluentes nascidos em locais muito diferenciados", afirma o escritor e ativista Herbert Daniel (DANIEL; PARKER, 2018, p. 90), ao refletir nas tantas camadas de preconceito que existem em torno da doença, criando um imenso estigma a ela associado.

Talvez, por viverem entre tantas condições de marginalização e violência social, com subjetividades feridas com tanta dor e estigma, estes sujeitos homossexuais das cenas do filme - como também de tantos cenários fora da ficção existentes no passado e presente - possam preferir tentar se esquivar da associação realizada violentamente entre eles e a aids. Associação esta que foi criminosa, rotulando homossexuais como corpos castigados pela doença, como reflete Jardim:

\begin{abstract}
A peste e a aids foram, nessas visões, castigos diferentes enviados por Deus para corrigir os pecados dos homens. O flagelo da peste foi lançado contra comunidades inteiras, como os egípcios no caso do Êxodo, e os habitantes de Londres e de Orã, nos livros de Daniel Defoe e de Camus. Já a aids atacou determinados setores da população - os grupos de risco. Foram quatro esses grupos: homossexuais masculinos, usuários de heroína, hemofílicos e haitianos. Por este motivo, a aids foi chamada de "doença dos quatro h". A noção de grupo de risco foi criada pela Epidemiologia em meados do século XX. Inicialmente, ela serviu para indicar a probabilidade da ocorrência de uma doença, ou de qualquer outro fator relacionado à saúde em uma população, durante um período de tempo. Era uma indicação estatística. Com a chegada da aids, vários outros significados se agregaram, desvirtuando o conceito original. A noção de grupo de risco deixou de ter um valor estatístico e passou a designar entidades culturalmente definidas, como homossexuais e usuários de drogas injetáveis. Estas comunidades, definidas na forma de tipos - o gay, o drogado - já não eram consideradas sujeitas a risco, mas passaram a ser elas próprias um perigo para o resto da população. Apenas mais um passo e atribuiu-se a elas a responsabilidade pela doença (JARDIM, 2019, p. 44).
\end{abstract}

Excluídos e marginalizados, os grupos mais afetados pela aids encontravam-se intensamente vulnerabilizados por estas condições sociais e culturais às quais foram submetidos. Surge então uma densa trama a se desenrolar: como discutir sobre 
prevenção e vulnerabilidade às infecções sem rotular estes grupos mais afetados como os únicos possíveis de serem infectados pelo vírus? Tramas delicadas, pois, naquele momento, era urgente pensar em medidas para frear a epidemia viral, porém a epidemia subjetiva também ganhava força ao estigmatizar mais ainda estes corpos já excluídos.

As cenas se seguem com diálogos em propostas para festas-militâncias coletivas, para uma parada que tomará as ruas. Um slogan é sugerido: “Talvez seja a minha última parada". A finitude da vida é deixada mais nítida a partir da doença e a frase sugerida lembra dessa fragilidade intensificada pelo vírus.

Segue-se com um corte. Entre a preparação-festiva e a festa, a cena seguinte ocorre em uma escola. Pode-se dizer que todo o filme é educativo pelas fissuras que provoca e nos afetos que engendra, mas este embate com as perspectivas de educação escolar é um marco: o coletivo organiza uma invasão-forçada em uma sala de aula de jovens sem a autorização da direção, contrariando uma educação maior para poder falar de prevenção, aids, sexualidade e cuidado com a vida. Sobre a educação maior, o filósofo e educador Sílvio Gallo (2002, p. 173) afirma que:

A educação maior é aquela dos planos decenais e das políticas públicas de educação, dos parâmetros e das diretrizes, (...) pensada e produzida pelas cabeças bem-pensantes a serviço do poder. A educação maior é aquela instituída e que quer instituir-se, fazer-se presente, fazer-se acontecer. A educação maior é aquela dos grandes mapas e projetos (GALLO, 2002, p. 173).

Em meio à educação maior "a serviço do poder" (GALLO, 2002, p. 173), acontece uma ruptura, uma quebra dos paradigmas morais, da dureza escolar, do conservadorismo, dos olhares que reprimem e que estigmatizam. Uma tentativa de quebra do estigma. Ao adentrarem de forma forçada nas salas de aula, os ativistas instauram uma educação menor ${ }^{12}$, refletindo juntamente de Gallo (2002):

12 Percebo que o filme possibilita criar um currículo menor em cinema e conecta com diversas potências em educações menores, sendo elas em HIV/aids, saúde, biologia e ciências. Outros importantes trabalhos que dialogam com este artigo são: "EDUCAÇÃO EM SAÚDE MENOR: análise de uma proposta de experimentação diante a epidemia de hiv e aids" de Vinícius Colussi Bastos (2020), no qual o autor reflete acerca de possibilidades de uma educação em saúde e HIV/aids menor; "Entre encontros e ensino de biologia e gêneros e sexualidades: sopros e insurgências de uma biologia menor" de Sandro Prado Santos e Matheus Moura Martins (2020); "Sexualidades e gêneros e educação em biologia menor e cartografias de suas pequenas redes em livros didáticos - PNLD/2018" de Sandro Prado Santos, Fabrício Aparecido Gomes da Silva e Matheus Moura Martins (2020); e "Educação em biologia menor: livros didáticos e redes possíveis de desterritorialização de gêneros e sexualidades" de Sandro Prado Santos, Elenita Pinheiro de Queiroz Silva e Matheus Moura Martins (2021), sendo que estes três últimos trabalhos cartografam as conexões entre ensino de biologia, gêneros, sexualidades e educação em biologia menor. 
Uma educação menor é um ato de revolta e de resistência. Revolta contra os fluxos instituídos, resistência às políticas impostas; sala de aula como trincheira, como a toca do rato, o buraco do cão. Sala de aula como espaço a partir do qual traçamos nossas estratégias, estabelecemos nossa militância, produzindo um presente e um futuro aquém ou para além de qualquer política educacional. Uma educação menor é um ato de singularização e de militância (GALLO, 2002, p. 173).

Os militantes em seus movimentos de matilha, em devir-lobo, instauram uma educação menor. Os professores entram em choque, em estados de revolta e raivosidade. Muitos alunos se interessam pelos temas até então marginalizados, excluídos e silenciados. Outros alunos entram em estado de negação de suas capacidades biológicas e sociais de serem afetados pelo vírus, como se a aids fosse apenas a doença do outro, não uma doença possível de acometer a qualquer um.

As cenas seguem com Nathan distribuindo materiais informativos sobre prevenção sexual durante o protesto no pátio escolar. Ele oferece o material para uma aluna e é repreendido por um gesto preconceituoso dela que, ao se reconhecer heterossexual, entendia que não precisava se proteger e previnir sexualmente, pois não poderia ser infectada pelo HIV e acometida pela aids.

Logo após a fala de repreensão e preconceito, uma cena instaura um corte entre homofobia e desejo. Sean beija Nathan em sua boca no meio do pátio escolar, retomando o tesão para este território educativo repleto de moralidades e conservadorismo. A professora e pesquisadora bell hooks afirma, ao refletir na importância do erotismo na educação, que “quando Eros está presente na sala de aula, é certo que o amor vai florescer" $(2013$, p. 262). A potência do desejo traz força para seguir em lutas coletivas em educações menores, seja nas salas de aula, pátios escolares, ruas, grupos de discussões e militâncias coletivas.

Uma nova quebra. Cenas de dança, música, luzes. Vida. Um filme que fala de aids é, antes de tudo, um filme que fala de vida. De vida que pulsa em batimentos que aceleram dentro do peito, do corpo, do beijo, do atrito dos corpos. Vidas que pulsam, que movimentam-se pelo tesão. Tesão esse que pode descarrilar-se em movimentos mortíferos mas, que sem ele, não existe vida. 120 Batimentos Por Minuto (2017) é um filme sobre contaminações: "uma experiência de relação com o outro, seja esse outro alguém que se expõe às contaminações com a vida ou alguém que as evita através das estratégias defensivas as mais variadas", como reflete o artista Paulo Buenoz (2009, p. 
235) ao relatar as experiências de um Corpo Cobaia em uma pesquisa de novos remédios para a aids.

Novamente um beijo. Cenas que migram da boate para o quarto de Sean, acompanhado de Nathan. Uma transa sorodiferente ${ }^{13}$, um diálogo sobre prevenção. Prevenção em múltiplas formas de contatos entre-corpos que fogem à falocêntrica percepção das relações sexuais como apenas penetração peniana. Prevenção no sexo oral pelo também uso do preservativo externo. Prazer além de qualquer medo ou perigo. "Positivos / e vivos / de pulso e impulso / e vão sem medo" (PÊRA, 2018, p. 140). Diálogo, conversa, troca, abertura. Ressonâncias do desejo contaminadas com a dor que permeia e é permeada pela aids. Uma fuga à condenação da morte social ao se infectar pelo HIV, "poder de contornar o deserto subjetivo que se desenha em torno da AIDS, em sua relação com o(s) outro(s), qualquer (quaisquer) que seja(m), quanto este(s) teme(m) o contágio" (BUENOZ, 2009, p. 235).

Diálogos entre Sean, uma pessoa que vive com HIV, e Nathan, uma pessoa que não vive com HIV. Ambos se envolvem sexualmente e afetivamente. E dialogam sobre responsabilidade. No sexo, prática consentida - excluindo casos de abusos e violências , os sujeitos lá envolvidos são responsáveis por suas escolhas: usar ou não o preservativo, como também outros métodos de prevenção, são decisões em movimentos de corresponsabilidade de todos. Sean, ao relatar como se infectou, comenta que "quando você contamina ${ }^{14}$ alguém, você é $100 \%$ responsável. Quando você é contaminado, também" ${ }^{\prime 15}$.

Nestas cenas, as imagens do filme focam nos corpos e também no preservativo, no prazer e no gozo. Retratos de sexo, diálogo e memórias. Os corpos-nus exercendo suas sexualidades são permeados por histórias, lembranças, prazeres, dores e delícias. $\mathrm{O}$ Sarcoma de Kaposi, um câncer comum em pessoas com aids caracterizado pela

\footnotetext{
${ }^{13}$ Utiliza-se o termo sorodiferente para relações em que uma pessoa tem sorologia positiva para o vírus HIV e a outra pessoa não.

${ }^{14}$ Saliento que o termo "contaminar/contaminação" pode carregar uma carga de estigma e preconceito, existindo discussões, principalmente nos movimentos sociais de HIV/aids, sobre a problemática de usá-lo, podendo participar da associação dos corpos vivendo com HIV/aids às noções estigmatizantes de "sujeira" e "impureza". Também existem movimentos de resistência em tentativas de criar outros sentidos para o uso da palavra e pensar na potência - artística, poética, e... - da "contaminação", produzindo discursos outros a fim de fugir de noções higienistas de limpeza e pureza. Eu, particularmente, prefiro o uso de "infectar/infecção" quando penso, escrevo e falo em infecções virais, como pelo HIV, ao invés de "contaminar/contaminação", por entender que corpos vivendo com quaisquer vírus-biológicos - seja o HIV, Sars Cov 2, HPV, dentre outros - não foram contaminados pelos vírus, mas sim infectados. No caso da fala presente no filme, o termo utilizado foi "contamina/contaminado" (contaminé, em francês) e escolhi mantê-lo.

${ }^{15}$ Fala presente no minuto 49 do filme.
} 
presença de grandes manchas escuras, povoa as cenas, tanto nas recordações de Nathan de outras transas, quanto no desabafo de Sean, relatando também ter o câncer em algumas partes do corpo.

Novos cortes acontecem em direção a cenas festivas, em uma parada de celebração nas ruas, como na Imagem 4. Parada, protesto, festa, desejo. Remédio? Drogas? Gritos? Vidas? Remédios, drogas, gritos e vidas misturados em euforias. Tudo, menos a morte. Talvez porque a morte se dissolva nestes currículos-cinematográficos como apenas um acontecimento dentre tantos outros, um fragmento da vida, seja ela em decorrência da aids ou não. Brilhos de celebração viralizam pelas cenas.

IMAGEM 4: Celebração-viral ou contaminações de vida.

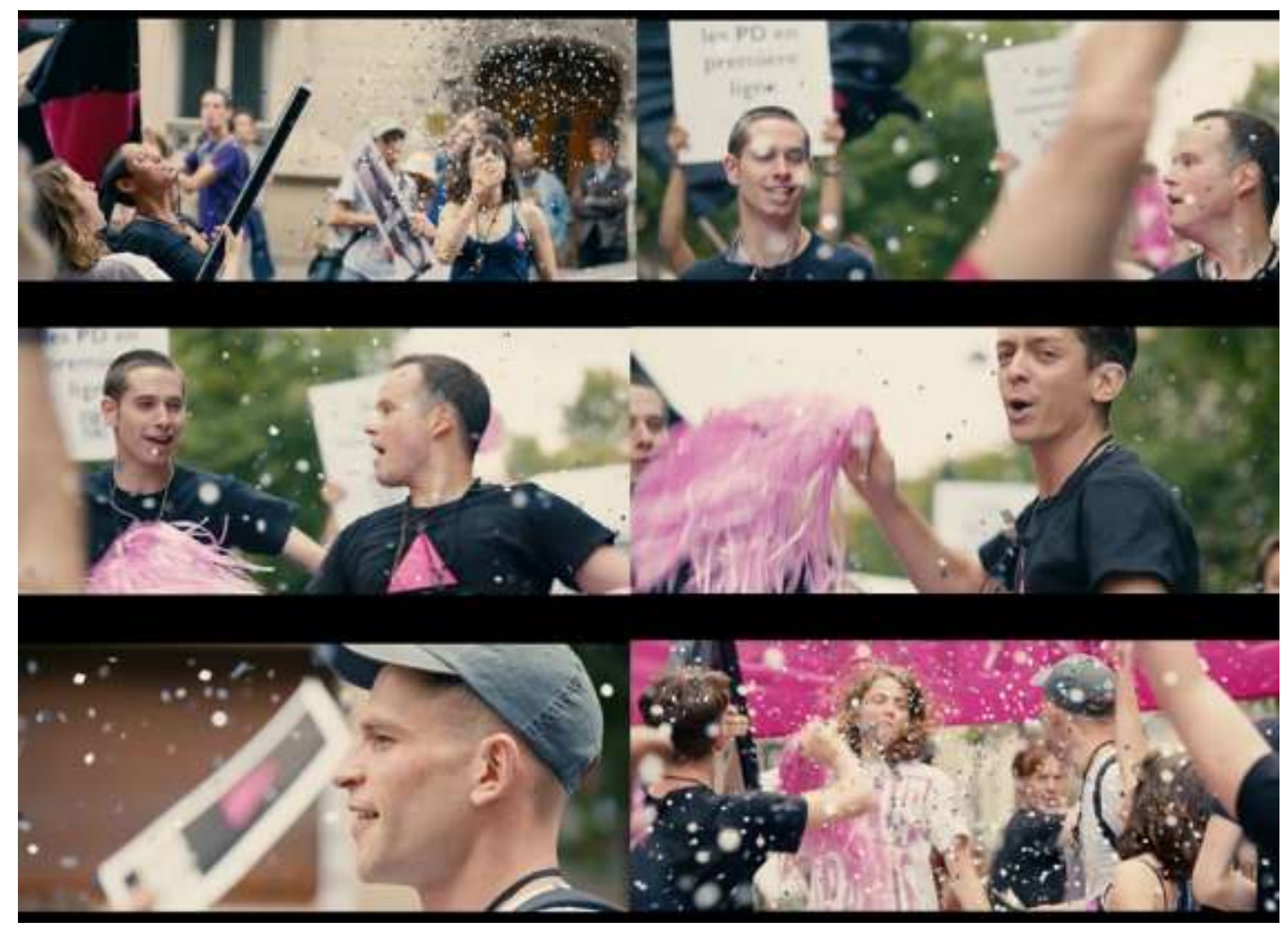

Fonte: Sequência de seis registros de cenas presentes nos minutos 56 e 57 do filme "120 Batimentos por Minuto" (2017).

Novas mudanças. Cenas de reuniões. Atritos entre militância e laboratórios farmacêuticos. Atritos dentro da própria militância. Os territórios atravessados pelo filme estão repletos de disputas a todo momento, em atritos entre tesão e tensão. Tesão e tensão que coexistem, se entremeiam, tensionam, misturam e se separam. Sobre as tramas existentes entre tesão, tensão e prevenção, reflito que: 
Talvez sejam pelas mesmas porosidades e fissuras que nos deixam mais vulneráveis a contaminações que encontremos fugas para pensar em caminhos possíveis por onde o desejo encontre passagem, sendo terreno fértil para a proliferação de embriões de possibilidades de viver e de ter tesão em meio a tantas tensões (SALES, 2020b, p. 26).

A morte, parte da vida, dissolvida viralmente pelos trajetos fílmicos, em alguns momentos ganha intensidade. Falar de aids é falar de vida. Falar de vida é falar também de morte. Falar de aids é falar de morte. Tantos milhões que morreram, tantos milhares que continuam perdendo suas vidas todos os dias. O adoecimento e morte fazem parte intensamente deste momento em que se passam as narrativas audiovisuais, no início da década de 1990, em que a militância convive com incontáveis mortes e adoecimentos diários.

Na continuação do filme, Jérémie e Sean têm seus estados de saúde agravados. Cenas ficcionais se misturam com filmagens documentais de protestos do ACT UP. Em instantes, Jérémie adoece, é internado e morre. Uma morte que afeta todos pela velocidade que ocorreu, pela impotência de pouco ou, muitas vezes, nada poder fazer para impedi-la. Um luto político é organizado para marcar a perda que a matilha sofreu a partir da morte do companheiro militante. Em carreata pelas ruas de Paris (Imagem 5), o coletivo segue em gritos, em movimentos de memória, defesa da vida e protesto em relação ao caos epidêmico vivido e tanto negligenciado.

IMAGEM 5: Lutas e lutos políticos.

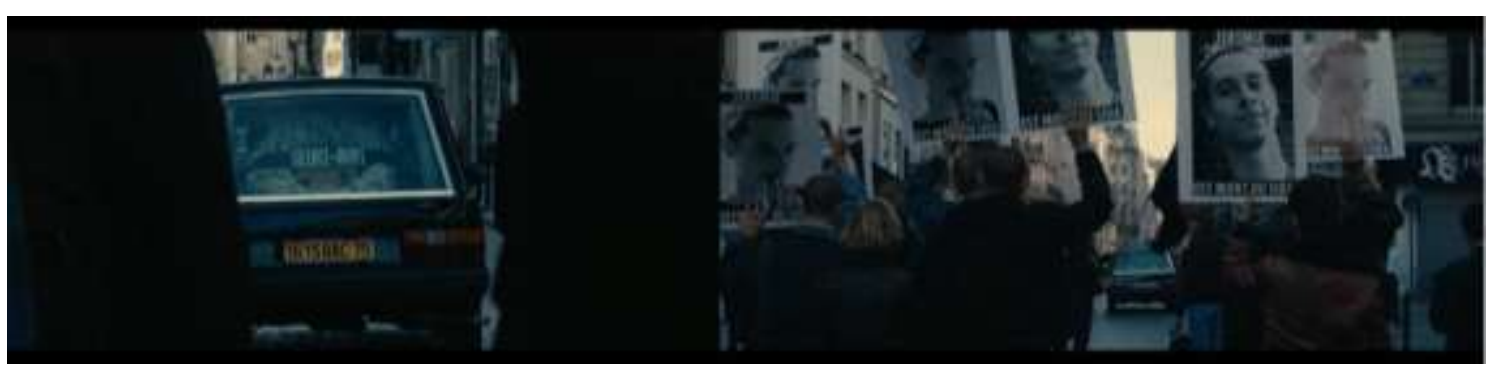

Fonte: Sequência de dois registros de cenas presentes nos minutos 73 e 74 do filme "120 Batimentos por Minuto" (2017).

Do velório-político pelas ruas, um deslocamento em closes transporta as próximas cenas para a cama, onde Sean e Nathan, em tons frios-escuros, se olham em silêncio. A imagem de um anticorpo repleto de micropartículas virais toma conta da tela (Imagem 6), se dissolvendo em águas e pessoas nadando. Quanto tempo resta para cada um? 
IMAGEM 6: Devires: danças anticorpos-vírus.

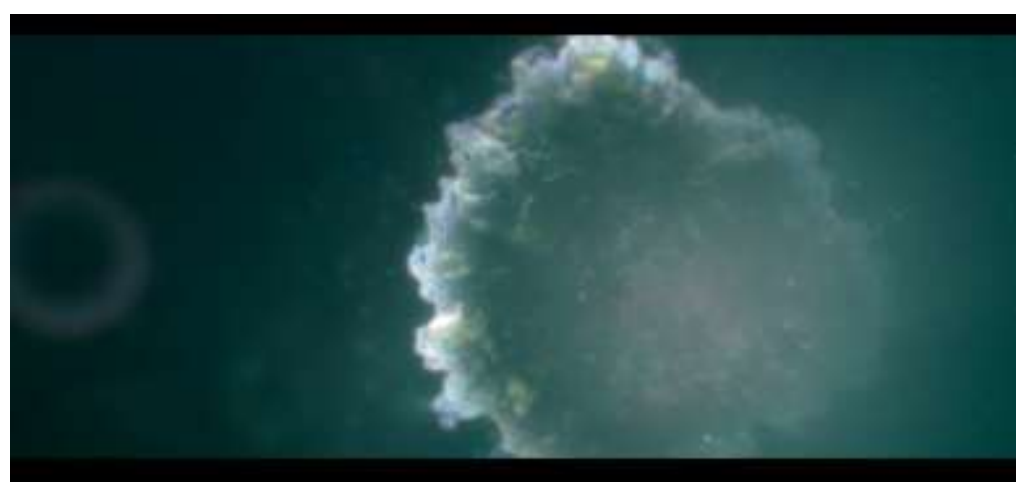

Fonte: Registro de cena presente no minuto 74 do filme "120 Batimentos por Minuto" (2017).

Uma reunião repleta de atritos preenche as cenas seguintes. Pautas diversas e, em muitos momentos, também conflitantes constituem o coletivo ACT UP. Um ato rapidamente reprimido que tentava distribuir seringas descartáveis para usuários de drogas injetáveis, em tentativas de prevenção entre tantos moralismos.

Kelly Gavigan, Ana Ramirez, Jack Milnor, Amaya Perez-Brumer, Veriano Terto Jr. e Richard Parker (2015) refletem nas pedagogias existentes e emergentes dos movimentos de HIV/aids, pensando em uma pedagogia do tratamento e na urgência de se desenvolver uma pedagogia da prevenção.

O conceito de pedagogia do tratamento desenvolvido por ativistas de HIV/AIDS no início da expansão do tratamento para o HIV, reconhece a necessidade de fazer mais do que simplesmente "colocar comprimidos dentro do corpo das pessoas', hoje precisamos desenvolver a pedagogia da prevenção para facilitar a resposta e o empoderamento daqueles em risco de infecção pelo vírus. A pedagogia do tratamento foi desenvolvida para ajudar as pessoas a transformar a promessa de acesso a tratamento em uma realidade em suas vidas. É igualmente importante, hoje, incorporar a pedagogia da prevenção no esforço pelo 'fim da AIDS', e permitir que os milhões em risco de infecção pelo HIV assumam o controle de todo o leque de opções de prevenção disponíveis (GAVIGAN et al, 2015, p. 4).

Estas pedagogias do tratamento buscavam "transformar as pessoas HIVpositivas em donas do seu próprio tratamento" (GAVIGAN et al, 2015, p. 4), empoderando-as. Estes movimentos sociais também lutavam para construir estratégias de prevenção que melhor os atendesse, fugindo de discursos biomédicos estigmatizantes e que limitavam a vida a processos biológicos, e o HIV/aids a processos infecciosos.

A pedagogia da prevenção, segundo a definição que adotamos aqui, vai muito além da capacidade de ler. Inclui a capacidade de processar e avaliar informações de saúde para tomar decisões baseadas no que é 
melhor para cada pessoa, de negociar e exigir o direito a essas opções e de discutir essas decisões com os parceiros e pares. A capacitação para a prevenção não significa apenas o processamento das informações, mas um processo de 'conscientização' e de empoderamento que permite às pessoas colocarem os conhecimentos em prática (GAVIGAN et al, 2015, p. 13).

Nos trajetos-militantes do filme, as narrativas audiovisuais atravessam o que entendo como possibilidades de pedagogias do tratamento e da prevenção, inspirados em Gavigan e colaboradores (2015). No tratamento, estas pedagogias acontecem ao empoderarem as pessoas vivendo com HIV e aids para terem acesso aos medicamentos disponíveis e lutarem pelos que ainda estavam em fase de testes, também adentrando laboratórios e enfrentando grandes indústrias farmacêuticas e o Estado que silenciava-se perante um genocídio. Na prevenção, ocorrem ao abordarem o uso do preservativo associado ao desejo, não colocando a pessoa com aids como sujeito sem vida e tesão, e também ao protestar nas ruas, becos e escolas, discutindo acerca de diferentes possibilidades de transmissão e prevenção ao HIV/aids. São pedagogias que chamo de menores, inspirado em Gallo (2002) e na discussão de uma educação menor.

A aids e o vírus como personagens presentes no filme, vão se entremeando por todas as cenas. Nathan relata como a doença perpassa sua vida sexual desde as suas primeiras relações, mesmo não tendo se infectado. Uma doença que afetou subjetividades diversas em corpos que vivem e convivem com o HIV. Enquanto Nathan relata sobre uma revista que teve contato anos antes, aparece em cena imagens de um casal gay aparentemente saudável e, posteriormente, o mesmo casal com um dos dois em estado terminal de aids. Essas fotos se referiam a Kenny Ramsauer, uma pessoa que faleceu em decorrência da aids e tornou-se uma figura emblemática ao ter fotos publicadas de seu corpo todo desconfigurado pela doença. Em flashes, aparecem suas fotos com o rosto modificado e disforme, e o corpo repleto de manchas de Sarcoma de Kaposi. Uma pedagogia do medo se instaurava naquele período, perdurando até hoje, e é relembrada no filme, produzindo um discurso de que todos os homossexuais morreriam em decorrência da aids, levando Nathan a ficar anos sem se relacionar sexualmente.

Nas próximas cenas Sean vai enfraquecendo gradativamente em decorrência da aids enquanto Nathan cuida dele. São movimentos de carinho e acolhimento. Ocorre um corte nas cenas entre Sean na cama recebendo líquidos intravenosamente com a ajuda de Nathan e os dois em uma boate com música e som. Em seguida, uma nova mudança 
de cenas transita para uma reunião. Sean está cada vez mais fraco. Durante uma reunião do coletivo-militante, flashes de memórias povoam as cenas: Sean em consultas médicas, Sean em um hospital. Quanto tempo resta? Quantos anticorpos? Seu corpo sobreviverá ao Sarcoma de Kaposi, às infecções oportunistas?

Imaginações que materializam-se em cenas de festas, paradas... Mas, novamente, uma questão me inquieta: Quanto tempo resta para Sean? Quanto tempo resta a tantos outros infectados pelo vírus? Será que conseguirão sobreviver até que os laboratórios farmacêuticos liberem os medicamentos a anos pesquisados mas morosamente dificultados para que cheguem às pessoas acometidas pela aids?

Cenas de uma viagem à praia. Junto de Sean e Nathan, também vai uma sacola de objetos biomédicos. Uma última viagem ao mar? Uma quebra. Sean aparece na cena seguinte novamente em um hospital. Furos na pele, exames, um corpo magro medicamente escrutinado enquanto assiste na televisão notícias de um mundo lá fora: fora dos muros do hospital. Uma visita, diálogos sobre dor, infecção e remédios que possam aliviar a insustentável e destrutiva doença que devora o corpo de Sean. A primeira visita vai-se embora e Nathan chega. Sean está muito mal, com dores e diversas infecções oportunistas.

“Tudo dói. Não sei mais se é febre ou medo ou ambos. Eu estou com medo. Eu estou com muito medo o tempo todo"16, desabafa Sean enquanto chora, acompanhado de Nathan. Nathan se aproxima e o beija em sua boca. A mão de Nathan adentra a calça de Sean, que permanece deitado na cama hospitalar, magro e com manchas de Sarcoma de Kaposi espalhadas pelo corpo. Enquanto se beijam, Sean treme de prazer entre resquícios do choro que existia momentos atrás. Um gozo nítido aparece em cena, juntamente dos risos dos dois. Sean, em estado avançado de aids, repleto de manchas causadas pelo câncer Sarcoma de Kaposi e de infecções oportunistas, é visto e reconhecido por Nathan como uma pessoa viva, dando vazão para seus desejos, seu prazer, sua vida, seu tesão (Imagem 7).

O desejo e tesão relacionados à aids, no filme, são permeados por linguagens biomédicas e marcas do corpo, compondo as experiências subjetivas afetadas pela epidemia. Uma vigília médica adentra a vida. Estes corpos permeados pelos olhares médicos insistem em manter-se vivos enquanto lá existir vida. O antropólogo Néstor Perlongher (1987), ao refletir sobre as tramas biomédicas existentes em torno da aids,

${ }^{16}$ Falas presentes no minuto 107. 
pensando na aids como um dispositivo, afirma que "a vida não se mede apenas, como quer a instituição médica, em termos de prolongação da sobrevida (ou da agonia), mas também em intensidade do gozo. A dimensão do desejo não deveria ser negligenciada, se é que se trata de salvar uma vida" (PERLONGHER, 1987. p. 92). Enquanto existe vida, ela não deve e nem pode ser negligenciada caso a intenção seja a preservação de uma vida. Silenciar e esconder a intensidade do gozo e a dimensão do desejo, como reflete Perlongher (1987), é caminhar em direção à morte.

IMAGEM 7: Transa ou desejos em fluxos entre corpos-vivos.

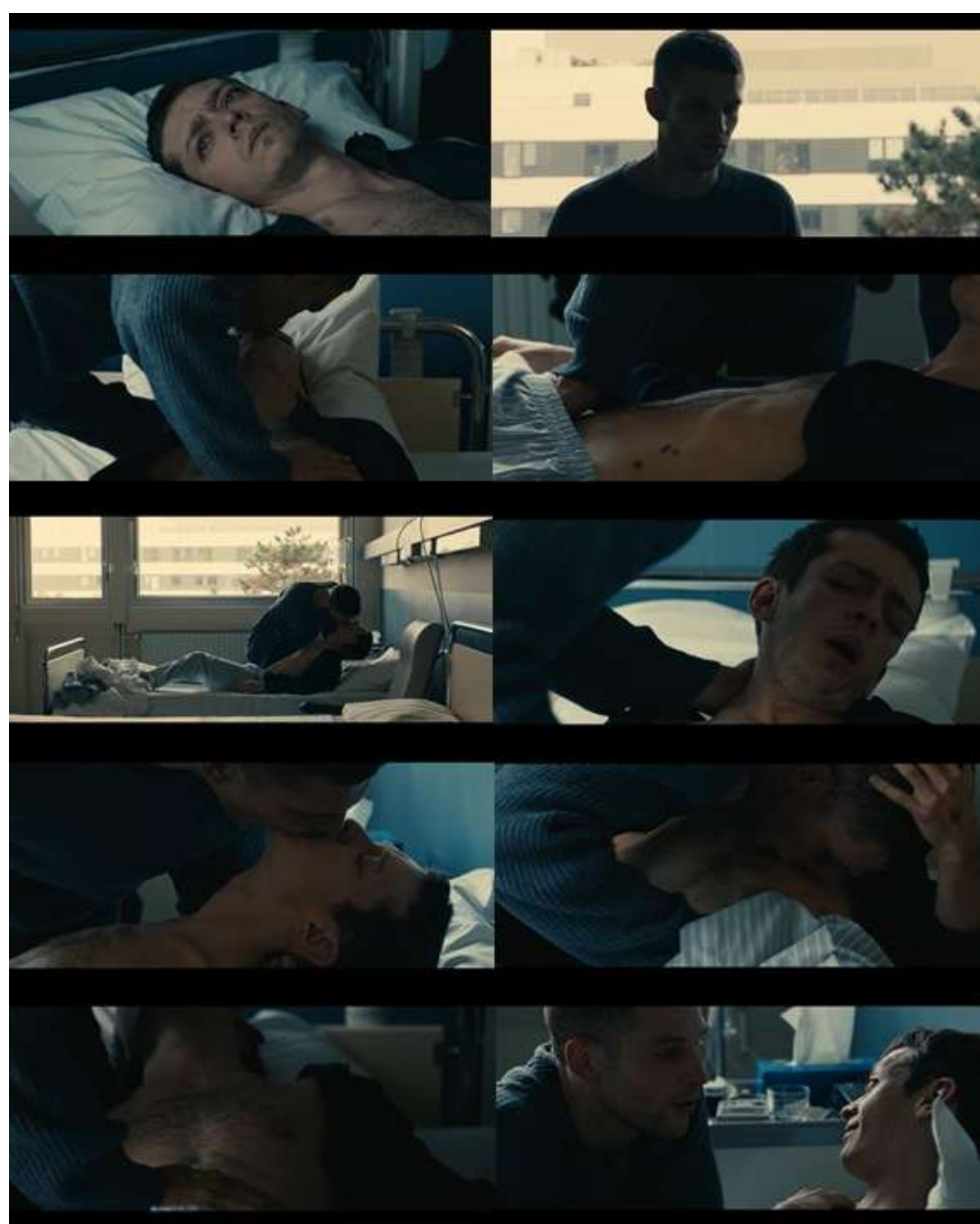

Fonte: Sequência de dez registros de cenas presentes nos minutos 109 e 110 do filme "120 Batimentos por Minuto" (2017).

Após o sexo no ambiente hospitalar, cenas de carinho, cuidado e acolhimento ganham espaço. Em seguida, novamente um corte. Cenas de um protesto (Imagem 8) 
que toma as ruas de Paris e quebra os silêncios da noite, da negligência e das políticas de morte. Todos se deitam no chão enquanto alguns pronunciam palavras de força e denúncia. Nathan chora. Quantos já morreram? Quantos mais morrerão?

IMAGEM 8: Protestos, lutas e lutos coletivos em tentativas de quebrar silêncios.

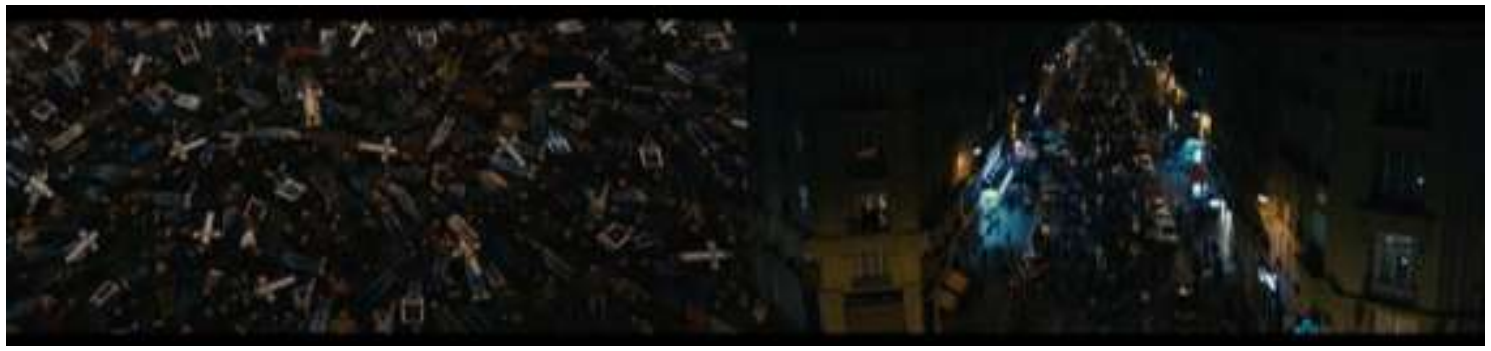

Fonte: Sequência de dois registros de cenas presentes no minuto 113 do filme "120 Batimentos por Minuto" (2017).

Cenas que migram das ruas para uma boate. Os personagens mantêm-se sempre vivos, até que a vida acabe. Nathan olha para os lados, mas parece que algo lhe falta. Na Imagem 9, micropartículas viralizam por todo o ar. Vírus? Quem poderá escapar? Todos se contaminam com estas microvidas contagiantes que preenchem os espaços entre danças, músicas, celebração e vida. Os personagens-vírus se contaminam subjetivamente pelos encontros e desejos.

IMAGEM 9: Contaminações subjetivas.

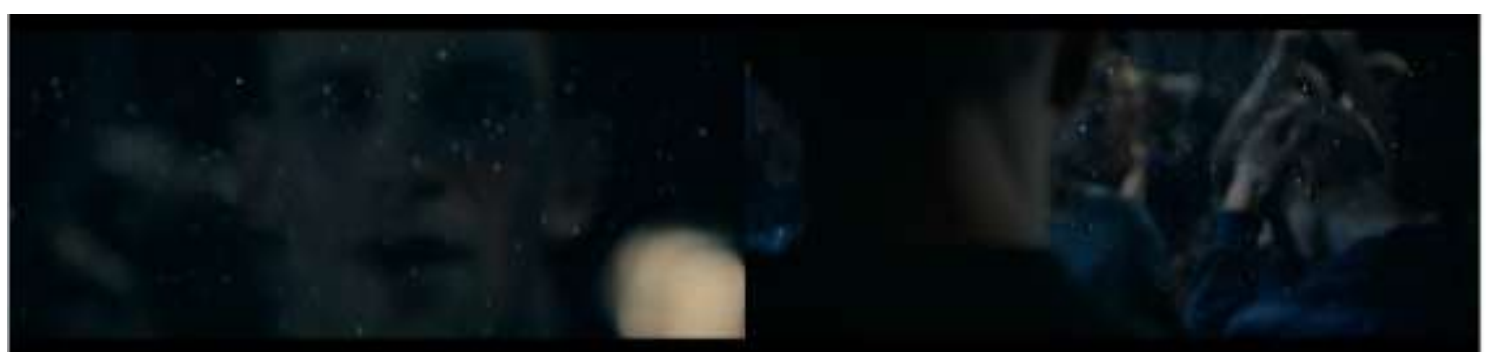

Fonte: Sequência de dois registros de cenas presentes no minuto 115 do filme "120 Batimentos por Minuto"(2017).

Envoltos, circundados, tomados, preenchidos por micropartículas. Um respiro. Em seguida, Sean aparece em cena no hospital. Um delírio? Sonho? Na Imagem 10, o registro de uma cena de um rio vermelho. Sangue? Morte? Vida? Sangue de tantos que se foram graças aos silêncios governamentais? Sangue que preenche cidades e campos, em um rio-vaso-sanguíneo de vida e também morte. 
IMAGEM 10: Rio-vaso-sanguíneo em contaminações.

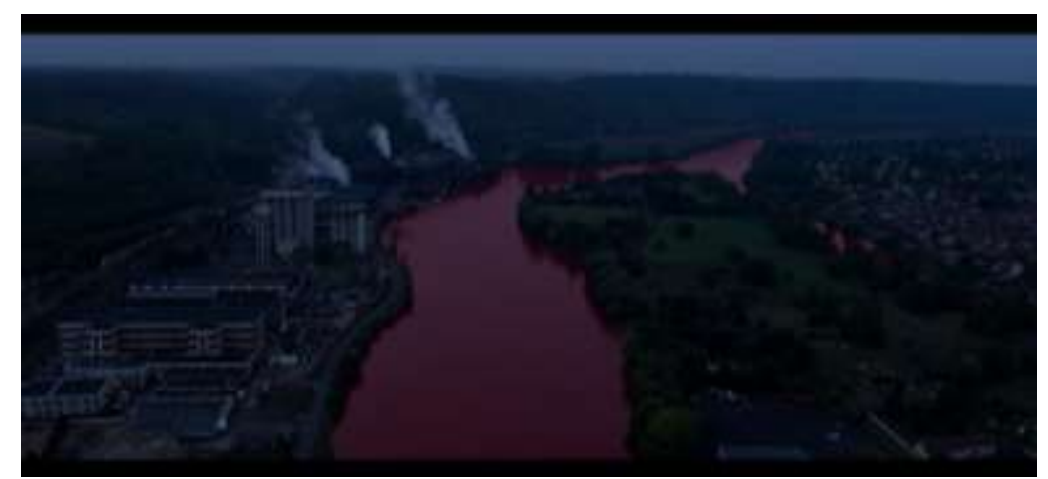

Fonte: Registro de cena presente no minuto 117 do filme "120 Batimentos por Minuto" (2017).

Inicia-se uma nova cena. Sean chega ao apartamento de Nathan, onde permanecerá. A mãe de Sean está lá e o ajuda. Sean chora inconsolavelmente. Logo depois ele aparece deitado, depois recebe ajuda de Nathan e de sua mãe para levantar. Enquanto toma banho deitado em uma banheira, sua mãe e Nathan olham para outros lados, até ouvirem um grito seu de ajuda. Sean, na próxima cena, aparece mais uma vez deitado, completamente esgotado. A vida vai se esvaindo. Em seguida, uma cena de uma conversa entre ele e Nathan deixa implícito um acordo. Um alívio combinado para frear a dor. Uma espera. Uma seringa, uma substância. Injeta-se no tubo que adentra intravenosamente o corpo de Sean. Esconde-se os vestígios. Apaga-se as luzes. Nathan se deita novamente e tenta dormir. Algum tempo depois, acorda, e olha para seu companheiro. Um medo de tocá-lo e descobrir o que já se sabia. Um toque que acontece em um corpo já sem vida.

Um grito de aviso, o anúncio de uma morte. Cenas de lágrimas e constatações de especialistas provam que aquele corpo na cama deitado já não está mais vivo. Pouco tempo depois chegam visitas no apartamento, em movimentos de conforto e despedida coletiva. Um corpo que é vestido para um adeus. Uma mãe que conversa com seu filho já sem vida enquanto tenta vesti-lo. Um café preparado, um beijo de cumprimento, um abraço de acolhimento, um estranhamento e desconforto constante. A pessoa que aparenta maior calma nesse momento é a mãe de Sean: estranhamente calma, paradoxalmente distante e presente.

As cenas seguintes acontecem em um velório na própria casa de Nathan, território dos últimos instantes de vida de Sean. Despedidas, um café, um luto compartilhado. Uma nota é escrita coletivamente para a imprensa. Com 26 anos, Sean morreu de aids. A mãe pede que o adjetivo "coragem" esteja presente no texto redigido para anunciar a morte do ativista. Ocorre um pedido dos companheiros de luta e 
militância para a mãe de Sean: que seja possível para ele um enterro político. Sabendo que esta era a vontade de seu filho, ela autoriza.

O dia amanhece, a vida de muitos continua. Cenas de Nathan transando com outro companheiro de militância se misturam com um protesto do ACT UP em um banquete requintado. No protesto, as cinzas de Sean são jogadas nas comidas servidas no evento, como era de seu desejo. Um luto político, cinzas que se viralizam em grito de anúncio de mais uma vida ceifada. As cenas se entremeiam: luto-protesto-sexo se misturando em beijos, gritos, corpos, danças. Corpos que agonizam e também tremem de prazer. Prazer e dor, vida e morte, saúde e doença se misturam entre luz e escuridão que também se bagunçam. Delírios? Músicas? Batimentos acelerados?

Silêncio.

\section{Transbordamentos e contaminações afetivo-educativas}

Nesta rede planetária de tecnocosmos, ciberespaço, reprodução regulada por computador, exploração genética, pedofilia em rede, fastfood googleano, bioética, biodiversidade, DNA, células tronco, idiotia comunicacional, automatismos informatizados, besteiras mecânicas e industriais, a Educação nos livra da Epistemologia da Pureza Essencial e da sua correspondente apreensão de seres, fenômenos e coisas estáveis, ao fazer a Diferença Pura, com sua capacidade de se multi-plicar? Ou nos encaminha, no máximo, até a variedade e a diversidade multiculturais, como sendo o Bem Máximo?

Sandra Mara Corazza (2010, p. 150).

O silêncio ao fim do filme dá espaço para um turbilhão de sensações que me atravessam. Pelo meu encontro com ele, os afetos borbulham. Ao me afetar, também aprendo com a produção audiovisual e seus currículos traçados, designados, construídos. Deslocado e inquieto nesta "rede planetária de tecnocosmos" (CORAZZA, 2010, p. 150) onde limites da vida humana-inumana-natural-artificial se borram e mostram-se produções, vejo as vidas-humanas sendo altamente ciborgues, como reflete Donna Haraway (2000).

Localizado atualmente em períodos cronologicamente distantes, aparentemente, dos momentos retratados nas narrativas do filme "120 Batimentos por Minuto" (2017), mas envolto em fortes conexões com os afetos lá potencializados, penso: De quais formas um filme pode vazar um currículo? Quais currículos são tensionados nesta 
produção audiovisual no que diz respeito à educação, sexualidade, HIV/aids, desejo, saúde, doença, vida e morte? Como eles reverberam em nossos dias?

Currículos não estão associados exclusivamente às escolas e lugares de educação institucionalizada, mas se fazem presentes em todos os territórios possíveis de se instaurar aprendizados e pedagogias. A partir do diálogo com autores do campo das Filosofias da Diferença como Deleuze, Guattari e Foucault, a pesquisadora Sandra Mara Corazza (2010) me inquieta a pensar em currículos (im)possíveis entre territórios neoliberais nos quais continuar respirando e permanecer vivo exige lutas diárias:

Neste momento de fascínio pela globalização econômica reprodutora e cultural homogeneizadora (em que comunidades e indivíduos portam um niilismo absoluto ou um pessimismo atávico), qual currículo, dentre os que conseguimos produzir, mantém-nos em devir-revolucionário (no domínio do indestrutível), para nos confrontar, radicalmente, aos abismos econômicos, sociais, tecnológicos, políticos? (CORAZZA, 2010, p. 149).

Corazza (2010) propõem a procura por um currículo que se baseie em geografias, um geocurrículo: "Quando designa as condições, das quais se desvia para criar a novidade, o pensamento curricular reconhece que a historiografia fornece apenas a atualização de variáveis para a forma histórica; enquanto a geografia lança eixos e orientações virtuais para um currículo poder devir" (CORAZZA, 2010, p. 153). Devir em um currículo a partir de pontos de vista, um currículo como ponto de vista, perspectivas, em movimentos de diferença, traçando cartografias, pois "não há vazio entre pontos de vista (em nosso caso, currículos) porque o espaço vazio não existe, já que tudo é força" (CORAZZA, 2010, p. 157). Assim, me coloco no movimento de pensar em um currículo que seja:

Leque a dobrar-se e desdobrar-se, dramatiza estranhos potenciais. Dotado de ligeireza, fantasia existências fragmentárias. Curvilíneo e turbilhonar, informa a bandidagem de naturezas descontínuas. Atravessador do Rubicão, tematiza a sua estética múltipla, que complica vários currículos. Abertura ao futuro, pensa de outra maneira: afirmativamente. Roubado ao além, reparte aprendizagens sem fim no espaço aberto. Alquimista em deslocamento, não entroniza a vida como sobrevivência. Arabesco esfumaçado de contornos, deixa-se ativar pela vida. Fabulosa reserva rizomática, existe para reinventar a vida. Sísmico, em labirintos, faz circular nuances infinitas da vida, pelas quais vale a pena constituir novos modos de existência (CORAZZA, 2010, p. 161).

Quais pontos de vista um filme possibilita? Quais brechas abre a partir de seus currículos? Quais currículos existem no filme “120 Batimentos por Minuto” (2017)? 
Quais currículos podem ser forjados a partir do e com o filme? Das salas de cinema para as casas, escolas, e... Pode o encontro com um filme ser aula? Filme, território de aprendizados, currículos-audiovisuais.

Nas narrativas audiovisuais de "120 Batimentos por Minuto" (2017) agenciamse currículos em torno da história do HIV/aids, em especial no início da década de 1990 na França. Mas, mais do que focar apenas naquele período e local, o filme permite traçar cartografias em torno de experiências subjetivas associadas ao vírus e processos a ele relacionados: diagnóstico, vida com o vírus, adoecimento, morte com o vírus, luta pela preservação da vida mesmo com o vírus.

Pedagogias audiovisuais são circunscritas pelas experiências dos personagens e pelas narrativas construídas no filme, traçando currículos e educações. Pedagogias do cinema? Cezar Migliorin e Elianne Barroso (2016, p. 17) refletem acerca de uma pedagogia do cinema:

Uma pedagogia do cinema, antes de estar relacionadas a certos conteúdos, se constitui como forma de conhecer e compartilhar conhecimento. (...) Uma pedagogia que não somente se concretiza pelo desejo de educar, o que certamente não é privilégio desses cineastas, mas, pela forma como criam, com a singularidade dos meios do cinema, um modo de pensar e efetivar essa educação na produção de sentidos à partir de elementos reais. $\mathrm{O}$ cinema como uma "aproximação crítica da realidade", como diria Paulo Freire (1996) em relação ao lugar do professor e do estudante (MIGLORIN; BARROSO, 2016, p. $17)$.

Os personagens, militantes no ACT UP de Paris, lutam em defesa do direito da vida das pessoas infectadas pelo HIV e em estado de aids, como também pela dissolução das tramas que se desenvolvem em torno da aids na forma de dispositivos, como reflete o filósofo Paul B. Preciado (2018, p. 355-356):

Enquanto teóricos queer formulavam sobre a performatividade de gênero e ativistas queer resistiam aos efeitos colaterais disciplinares das políticas de identidade gays e lésbicas, ativistas do ACT UP inventaram as primeiras estratégias que no contexto do neoliberalismo já poderiam ser chamadas de "ativismo antifarmacopornográfico": a luta contra a aids tornou-se a luta contra os dispositivos geopolíticos e culturais de produção da aids - o que inclui modelos biomédicos, campanhas publicitárias, organizações governamentais e não governamentais de saúde, programas de sequência de genoma, indústrias farmacológicas, propriedade intelectual, biopatentes, marcas, definições de grupo de risco, ensaios e protocolos clínicos... (PRECIADO, 2018, p. 355-356). 
A luta do movimento focava-se na dissolução de dispositivos que agenciavam vidas e subjetividades. No filme, além da dimensão de militar e lutar, são delineadas narrativas em torno da vida dos personagens, mostrando-os não como apenas militantes e/ou pessoas com HIV/aids, mas pessoas vivas, corpos-vibrantes em desejos, rizomando militância-desejo-luta-vida em narrativas audiovisuais. As cenas não se limitam à luta, pois a maior força existente acontece pelos movimentos em potências de vida, se entrelaçando com movimentos de luta, desejo, protesto, tesão, e... Assim, traçam-se currículos tênues que, na medida em que dissolvem dispositivos historicamente arquitetados em torno da aids, também devolvem subjetivamente a potência de vida e o desejo que foram anteriormente capturados por dispositivos biomédicos e políticas necrófilas produzidas em torno das pessoas com HIV e aids.

Em narrativas que se misturam em climas festivos, permeadas de partículasvirais, a produção cria trajetos-currículos que confundem-se entre militância, festa, dor, celebração, sofrimento, tesão, morte, luta e vida. Estas micropartículas que permeiam as cenas, em batimentos que aceleram e em intensidades, propõem pedagogias do contágio. Não um contágio pelo HIV, mas contagiar-se subjetivamente ${ }^{17}$ em vidas, potências, desejos. Contagiar-se pelo outro, pelas diferenças. Santiago Diaz (2020) propõem, ao pensar nos impactos pandêmicos contemporâneos com o covid-19, uma contra-pedagogia do contágio:

A contra-pedagogia do vírus é um contágio minúsculo, ínfimo e quase
imperceptível que desarruma toda a nossa integridade; é como o desejo,
o vírus é erótico - uma erótica viral? - porque nos infecta e nos
potencializa, singular e coletivamente, à força de nos refazer em todas
as relações, em tudo o que fazemos, sentimos e necessitamos. O vírus
desdobra toda uma contra-pedagogia da vida organizada, do tempo
regulado, da continuidade infértil das rotinas. Talvez seja hora de
deixar passar o vírus e sua pedagogia erótico-política. (...) Além disso,
torna-se necessária a elaboração de uma ética desejante que nos torne
dignos do que essa erótica do contágio nos faz sentir, porque o
sabemos: o desejo contagia e a paixão transborda. (...) A pergunta que
fica é evidente: como imaginar uma proliferação, uma propagação, um
devir, um contágio sem filiação ou produção hereditária? A erótica do

${ }^{17}$ No meu artigo "Entre tesões, tensões e prevenções: HIV/Aids e contaminações com as obras de Adriana Bertini" (SALES, 2020b), reflito um pouco nesta dimensão dos contágios e contaminações subjetivas. Um trecho presente no texto que acredito que pode ajudar nesta compreensão é: "O que fazer com tanto estigma, discriminação, preconceito, silêncio e desinformação nessa pandemia? Penso em caminhos através da informação e da abertura subjetiva a contaminações - reforço que aqui digo contaminação jamais fazendo apologia a possíveis infecções forçadas e intencionais a qualquer ser biológico-infeccioso, mas sim remetendo aos processos afetivos-subjetivos de se abrir ao que de diferente existe no outro e nos permitir ser atravessado por isso, nos tornando também outros. Qual é a nossa abertura para a diferença? Para pensar e falar em sexo e sexualidade e prevenção e ISTs e corpo e gozo e dor e amor e afeto e diferença e... e... e..." (SALES, 2020b, p. 23). 
contágio nada tem de paixão ou filiação identitária: há uma necessidade imperiosa que se transforma na aberrante atitude de trans-figurar toda valorização ingênua e fazer da desobediência mais minúscula, cuidada na proximidade, no mínimo toque (DIAZ, 2020, p. 170).

Em movimentos-contágios, instauram-se contra-pedagogias, militâncias e micro-educações nos currículos-audiovisuais. Movidos pelo desejo em forças de vida. "A potência contra-pedagógica do vírus é trazer-nos este antigo saber: que a vida prolifera heterogeneamente entre os corpos, entre as espécies, entre os 'reinos', que compõem a infinita e inalcançável presença contemporânea do vivente" (DIAZ, 2020, p. 171). No filme, o vírus também escreve os currículos lá instaurados, ensinando possibilidades de contagiar não com morte, mas com vida. A vida não se encerra a partir da infecção, da soropositividade ou da doença, pois, enquanto o corpo está vibrando, continua vivo. E, mesmo após a morte, permanece vivo nas marcas e afetos engendrados nos tantos outros contaminados-subjetivamente por uma vida. Contágiosmemórias, contágios-desejos, contágios-f(r)estas, contágios-lutos, contágios-lutas.

A partir dessa complexidade instaurada nos currículos-audiovisuais, os personagens não são reduzidos ao ativismo, assim como as pessoas infectadas e doentes não são limitadas ao vírus e à doença. Pelo contrário, fala-se em prazer, tesão e vida. “120 Batimentos por Minuto" (2017) é um filme que retoma o direito ao prazer, vida, desejo, tesão e gozo à pessoa que vive com HIV e aids ${ }^{18}$.

Herbert Daniel, no começo da década de 1990, denunciava a morte civil que matava a pessoa com aids antes mesmo de sua morte biológica. Ao viver com aids, ele afirmava que "o doente é visto como um morto, para quem nada adianta fazer, senão esperar o óbito" (DANIEL; PARKER, 2018, p. 46), na medida em que enfrentava esse espaço de morte civil e lutava por um posicionamento coletivo de reconhecimento da vida existente nas pessoas com HIV e aids.

O filme "120 Batimentos por Minuto" (2017) é uma produção que atua em movimento inverso ao de fortalecer a morte em vida das pessoas vivendo com HIV e aids. Na medida em que traça cenas de festa, celebração, desejo e vida, mesmo que povoadas por micropartículas virais, ele vai na direção contrária das políticas que Michel Foucault (2013) anunciava relacionadas ao poder sobre a vida que caracterizavam-se por "um poder de causar a vida ou devolver à morte" (FOUCAULT,

\footnotetext{
${ }^{18}$ Muitas destas reflexões são inspiradas nos encontros vividos no curso COMO ELIMINAR MONSTROS: DISCURSOS ARTÍSTICOS SOBRE HIV/AIDS, organizado e ministrado por Ronaldo Serruya e Fabiano de Freitas, que tive a alegria de participar em três edições no ano de 2020.
} 
2013, p. 150). O filme, mais do que deixar viver, impulsiona a vida, movimentando-a e fortificando-a.

No filme, enquanto há vida, também há movimento, desejo, força e potência. Nele, não se deixa que o estigma cerceie o tesão. Não se nega a dimensão de sofrimento relacionado à infecção, adoecimento e morte, mas permite-se acolhimentos e lutas em bandos, em matilha. O filme não nega a dor, mas possibilita com ela a instauração de refúgios. Em climas festivos e vibrantes, da luta ao luto, a produção audiovisual não deixa que o estigma mate o tesão e o desejo de vida. Assim, em suas cenas instauram-se pedagogias, traçam-se currículos de vida, desarticulando estigmas e consolidando perspectivas de potências do desejo, de devires, de resistência em defesa do tesão e da multiplicidade. Em devir-lobo (DELEUZE; GUATTARI, 2011), os personagens caminham em direções de vida, até ao se relacionarem com sua morte e de outras pessoas. Assim, mesmo que dentro de um filme advindo de espaços maiores da produção cinematográfica europeia, são engendradas pedagogias e currículos em movimentos-resistências pelos territórios menores de uma educação e um cinema.

\section{Agradecimentos:}

Essas e tantas outras reflexões em relação ao filme "120 Batimentos Por Minuto" (2017) e outras produções artísticas só foram possíveis graças aos meus encontros com muitas outras vidas. Agradeço, em especial, ao Coletivo HIV/artes pelos potentes encontros e discussões em profundidades teóricas e afetivas; e ao Ronaldo Serruya e Fabiano de Freitas pelo curso incrível e transformador COMO ELIMINAR MONSTROS: DISCURSOS ARTÍSTICOS SOBRE HIV/AIDS em suas diferentes edições, às quais tive a alegria de poder participar durante três vezes. Nesses encontros contaminei-me com muitas das reflexões que foram posteriormente elaboradas e materializadas nesses e em outros escritos.

\section{Referências:}

BASTOS, Vinícius Colussi. EDUCAÇÃO EM SAÚDE MENOR: análise de uma proposta de experimentação diante a epidemia de hiv e aids. In: FALEIRO, Wender; SANTOS, Sandro Prado; SANGALLI, Andreia. Ciências da Natureza para a diversidade. Goiânia: Kelps, 2020. Cap. 9. p. 212-240. 
BUENOZ, Paulo Lima. CorpoCobaia e o Caderno das Contaminações. Bagoas: Revista de Estudos Gays: Gênero e Sexualidades. v. 3, n. 4, p. 233-270, 2009

CORAZZA, Sandra Mara. OS SENTIDOS DO CURRÍCULO. Teias, Rio de Janeiro, v. 11, n. 22, p. 149-164, ago. 2010.

DANIEL, Herbert; PARKER, Richard. AIDS: A TERCEIRA EPIDEMIA: ensaios e tentativas. 2. ed. Rio de Janeiro: ABIA - Associação Brasileira Interdisciplinar de AIDS, 2018. 146 p. Disponível em: http://abiaids.org.br/wp-

content/uploads/2018/12/aids_a_terceira_epidemia_web.pdf. Acesso em: 24 nov. 2020.

DELEUZE, Gilles; GUATTARI, Félix. Mil platôs: Capitalismo e esquizofrenia. Vol. I. São Paulo, Ed. 34. 2011.

DELEUZE, Gilles; PARNET, Claire. Abecedário de Gilles Deleuze. Éditions Montparnasse, Paris. Filmado em 1988-1989. Publicado em: 1995.

DELEUZE, Gilles; PARNET, Claire. Diálogos. São Paulo: Escuta, 1998. 184 p.

DIAZ, Santiago. Contra-pedagogia do contágio. Ecos: Estudos Contemporâneos da Subjetividade, v. 2, n. 10, p. 169-172, 2020.

ELLSWORTH, Elizabeth. Modos de endereçamento: uma coisa de cinema; uma coisa de educação também. In: SILVA, Tomaz Tadeu da. (org.). Nunca fomos humanos nos rastros do sujeito. Belo Horizonte: Autêntica, 2001, p. 07 - 76.

FOUCAULT, Michel. História da Sexualidade I: a vontade de saber. 23. ed. Rio de Janeiro: Graal, 2013. 176 p.

GALLO, Sílvio. EM TORNO DE UMA EDUCAÇÃO MENOR. Educação \& Realidade, Porto Alegre, v. 2, n. 27, p. 169-178, jul-dez. 2002. Disponível em: https://seer.ufrgs.br/educacaoerealidade/article/view/25926/15194. Acesso em: 04 fev. 2021.

GAVIGAN, Kelly; RAMIREZ, Ana; MILNOR, Jack; PEREZ-BRUMER, Amaya; TERTO JUNIOR, Veriano; PARKER, Richard. Pedagogia da Prevenção: reinventando a prevenção do HIV no século XXI. Abia - Associação Brasileira Interdisciplinar de Aids: Perspectiva Política, Rio de Janeiro, n. 1, p. 1-16, nov. 2015. Disponível em: http://abiaids.org.br/wp-content/uploads/2015/11/PolicyBrief_portugues_jan2016.pdf. Acesso em: 23 nov. 2020.

HARAWAY, Donna. Manifesto ciborgue: ciência, tecnologia e feminismo-socialista no final do século xx. In: HARAWAY, Donna; KUNZRU, Hari; TADEU, Tomaz.

Antropologia do ciborgue: as vertigens do pós-humano. 2. ed. Belo Horizonte: Autêntica, 2000. p. 33-118.

hooks, bell. Ensinando a transgredir: a educação como prática da liberdade. São Paulo: Wmf Martins Fontes, 2013. 
JARDIM, Eduardo. A doença e o tempo: aids, uma história de todos nós. Rio de Janeiro: Bazar do Tempo, 2019, 80 p.

LOURO, Guacira Lopes. "O cinema como pedagogia”. In: LOPES, Eliane Marta Teixeira; FARIA FILHO, Luciano Mendes de; VEIGA, Cynthia Greive (Orgs.). 500 anos de educação no Brasil. Belo Horizonte: Autêntica, 2000.

MIGLIORIN, Cezar; BARROSO, Elianne Ivo. Pedagogias do cinema: montagem. Significação: Revista de Cultura Audiovisual, v. 44, n. 46, p. 15-28, 2016.

PÊRA, Amora. Amor Contágio. In: MELLO, Ramon Nunes. TENTE ENTENDER O QUE TENTO DIZER: poesia + hiv / aids. Rio de Janeiro: Bazar do Tempo, 2018. p. 138-140.

PERLONGHER, Néstor. O QUE É AIDS. 2. ed. São Paulo: Editora Brasiliense, 1987. $92 \mathrm{p}$.

PRECIADO, Paul B.. Testo Junkie: sexo, drogas e biopolítica na era farmacopornográfica. São Paulo: n-1 edições, 2018

ROLNIK, Suely. Cartografia Sentimental: transformações contemporâneas do desejo. Porto Alegre: Sulina, Editora da UFRGS, 2011. 247 p.

SALES, Tiago Amaral. Cartografias do cerrado: devires, marcas e forrageios em processos de pesquisa-trans-formação de um biólogo. Revista de Ensino de Biologia da SBEnBio, [S. 1.], v. 13, n. 2, p. 466-482, 2020a. DOI: 10.46667/renbio.v13i2.358. Disponível em: http://sbenbio.journals.com.br/index.php/sbenbio/article/view/358. Acesso em: 5 jul. 2021.

SALES, Tiago Amaral. Entre tesões, tensões e prevenções: HIV/Aids e contaminações com as obras de Adriana Bertini. ClimaCom - Epidemiologias [Online], Campinas, ano 7, n. 19, Dez. 2020b. Available from: http://climacom.mudancasclimaticas.net.br/entre-tensoes-prevencoes-2/

SALES, Tiago Amaral. Os ventos do norte também podem mover moinhos? "Como sobreviver a uma praga" e respostas à epidemia de HIV/aids. Bagoas: Revista de Estudos Gays: Gênero e Sexualidades. v. 14, n. 22, p. 244-281. 2021. Disponível em: https://periodicos.ufrn.br/bagoas/article/view/22759. Acesso em: 9 jul. 2021.

SALES, Tiago Amaral; ESTEVINHO, Lúcia de Fátima Dinelli. Carta para além dos muros biológicos: pistas de uma biologia menor e afetos possíveis com um documentário sobre HIV/AIDS. Revista de Ensino de Biologia da SBEnBio, [S. 1.], v. 14, n. 1, p. 290-311, 2021b. DOI: 10.46667/renbio.v14i1.484. Disponível em: https://sbenbio.journals.com.br/index.php/sbenbio/article/view/484. Acesso em: 5 jul. 2021.

SALES, Tiago Amaral; ESTEVINHO, Lúcia de Fátima Dinelli. Cartografias de vida-emorte em territórios pandêmicos: marcas-ferida, necro-bio-políticas e linhas de fuga.

Revista M. Estudos sobre a morte, os mortos e o morrer, Rio de Janeiro, v. 6, n. 11, 
p. 275-293, 2021a. Disponível em: http://seer.unirio.br/revistam/article/view/10487. Acesso em: 5 jul. 2021

SANTOS, Sandro Prado; SILVA, Elenita Pinheiro de Queiroz; MARTINS, Matheus Moura. Educação em biologia menor. Instrumento: Revista de Estudo e Pesquisa em Educação, Juiz de Fora, v. 23, n. 2, p. 382-398, 30 jun. 2021. Universidade Federal de Juiz de Fora. http://dx.doi.org/10.34019/1984-5499.2021.v23.33778.

SANTOS, Sandro Prado; MARTINS, Matheus Moura. Entre encontros e ensino de biologia e gêneros e sexualidades: sopros e insurgências de uma biologia menor.

Revista de Ensino de Biologia da SBEnBio, v. 13, n. 1, p. 141-152, 2020. DOI: 10.46667/renbio.v13i1.314. Disponível em: http://sbenbio.journals.com.br/index.php/sbenbio/article/view/314. Acesso em: 16 de jun. 2021

SANTOS, Sandro Prado; SILVA, Fabricio Aparecido Gomes da; MARTINS, Matheus Moura. Sexualidades e gêneros e educação em biologia menor e cartografias de suas pequenas redes em livros didáticos - PNLD/2018. Revista Diversidade e Educação, Rio Grande, RS, v. 9, n. Especial, p. 552-575, 2021. DOI:

10.14295/de.v9iEspecial.12626. Disponível em: https://periodicos.furg.br/divedu/article/view/12626. Acesso em: 16 de jun. 2021

SILVA, Tomaz Tadeu da. A arte do encontro e da composição: Spinoza + Currículo + Deleuze. Educação \& Realidade, Porto Alegre (RS), v. 27, n.2, p. 47-57, 2002.

SILVA, Tomaz Tadeu da. Documentos de identidade: uma introdução às teorias do currículo. Belo Horizonte: Autêntica, 1999. 156 p.

TSING, Anna. Viver nas ruínas: paisagens multiespécies no Antropoceno. Brasília: IEB Mil Folhas, 2019. 284 p.

UNAIDS. ESTATÍSTICAS MUNDIAIS SOBRE O HIV: RESUMO

INFORMATIVO. 2020. Disponível em: https://unaids.org.br/wpcontent/uploads/2020/11/2020_11_19_UNAIDS_FactSheet_PORT_Revisada.pdf. Acesso em: 23 nov. 2020. 